\title{
Population trends of waders on their boreal and arctic breeding grounds in northern Europe
}

\author{
Lindström, Å.
}

2019

Lindström , Å, Green , M , Husby , M , Kålås , J A , Lehikoinen , A \& Stjernman , M 2019 , ' Population trends of waders on their boreal and arctic breeding grounds in northern Europe ' , Wader Study, vol. 126 , no. 3 , pp. 200-216 . https://doi.org/10.18194/ws.00167

http://hdl.handle.net/10138/327094

https://doi.org/10.18194/ws.00167

publishedVersion

Downloaded from Helda, University of Helsinki institutional repository.

This is an electronic reprint of the original article.

This reprint may differ from the original in pagination and typographic detail.

Please cite the original version. 


\title{
Population trends of waders on their boreal and arctic breeding grounds in northern Europe
}

\author{
Åke Lindström ${ }^{1 *}$, Martin Green ${ }^{1}$, Magne Husby ${ }^{2,3}$, John Atle Kålås ${ }^{4}$, Aleksi Lehikoinen ${ }^{5}$ \\ \& Martin Stjernman ${ }^{1}$ \\ ${ }^{1}$ Department of Biology, Biodiversity Unit, Lund University, Ecology Building, SE-223 62 Lund, Sweden \\ ${ }^{2}$ Section of Science, Nord University, Røstad, NO-7600 Levanger, Norway \\ ${ }^{3}$ BirdLife Norway, Sandgata 30 B, NO-7012 Trondheim, Norway \\ ${ }^{4}$ Norwegian Institute for Nature Research, P.O. Box 5685 Torgarden, NO-7485 Trondheim, Norway \\ ${ }^{5}$ Finnish Museum of Natural History, FI-00014 University of Helsinki, Finland \\ *Corresponding author: ake.lindstrom@biol.lu.se
}

Lindström, Å., M. Green, M. Husby, J.A. Kålås, A. Lehikoinen \& M. Stjernman. 2019. Population trends of waders on their boreal and arctic breeding grounds in northern Europe. Wader Study 126(3): 200-216.

Waders form a conspicuous part of the bird fauna in boreal and arctic areas, where they inhabit forests, wetlands, mires and tundra. These are important breeding areas for a large set of wader species, and may be particularly vulnerable to climate change. However, large-scale and systematic monitoring data from the breeding grounds of boreal and arctic waders are largely lacking. We present population trends for 22 wader species breeding in the boreal and arctic parts of Fennoscandia (Norway, Sweden and Finland) between 2006 and 2018. The trends are based on 9,713 surveys of 1,505 unique routes $(6-8 \mathrm{~km})$, each surveyed in at least two years, evenly distributed over an area of $\sim 1$ million $\mathrm{km}^{2}$. The trends were significantly negative for three species: Red-necked Phalarope Phalaropus lobatus $\left(-7.9 \%\right.$ year $\left.{ }^{-1}\right)$, Broad-billed Sandpiper Calidris falcinellus $\left(-5.4 \%\right.$ year $\left.{ }^{-1}\right)$, and Whimbrel Numenius phaeopus $\left(-1.3 \%\right.$ year $\left.^{-1}\right)$. The trends were significantly positive for three species: Oystercatcher Haematopus ostralegus $\left(+4.9 \%\right.$ year $\left.{ }^{-1}\right)$, Dunlin Calidris a. alpina $\left(+4.2 \%\right.$ year $\left.{ }^{-1}\right)$ and Wood Sandpiper Tringa glareola $(+0.8 \%$ year $\left.{ }^{-1}\right)$. For the remaining species, we found no statistically significant trends. On average, as shown by a multi-species indicator, there was no general change in numbers over time. On 1,539 routes with at least one survey, wader species richness as well as total number of wader pairs increased significantly with increasing latitude. Species population trend was not correlated with breeding latitude, but population trends of long-distance migrants tended to be more negative than those of medium-distance migrants. The recent fortunes of waders breeding in northern Fennoscandia have been more buoyant than those in other parts of Europe, but the trends for some species are worrying.

\section{Keywords}

monitoring

species richness

multi-species indicator

total abundance

shorebirds

\section{INTRODUCTION}

Many waders breed partly or exclusively in boreal and arctic areas, where they inhabit forests, wetlands, mires and tundra (Järvinen \& Väisänen 1978, Lappo et al. 2012, Wetlands International 2012). Not only are these areas important for a large set of wader species, they may be particularly vulnerable to climate change, since climate, not least temperature, is expected to change faster in high latitude areas than elsewhere (IPCC 2014). Increasing summer temperatures can have drastic effects on arctic- breeding waders through their influence on habitat structure, food availability and predator-prey interactions (e.g. Lindström \& Agrell 1999, Rehfisch \& Crick 2003, van Gils et al. 2016). Furthermore, other environmental changes, such as habitat degradation of peatlands, can also contribute to declining populations of northern mire birds, including waders (Fraixedas et al. 2017).

Many wader populations around the world, including several breeding in the far north, have declined dramatically in recent times (Wetlands International 2012, BirdLife International 2015, Studds et al. 2017). However, large- 


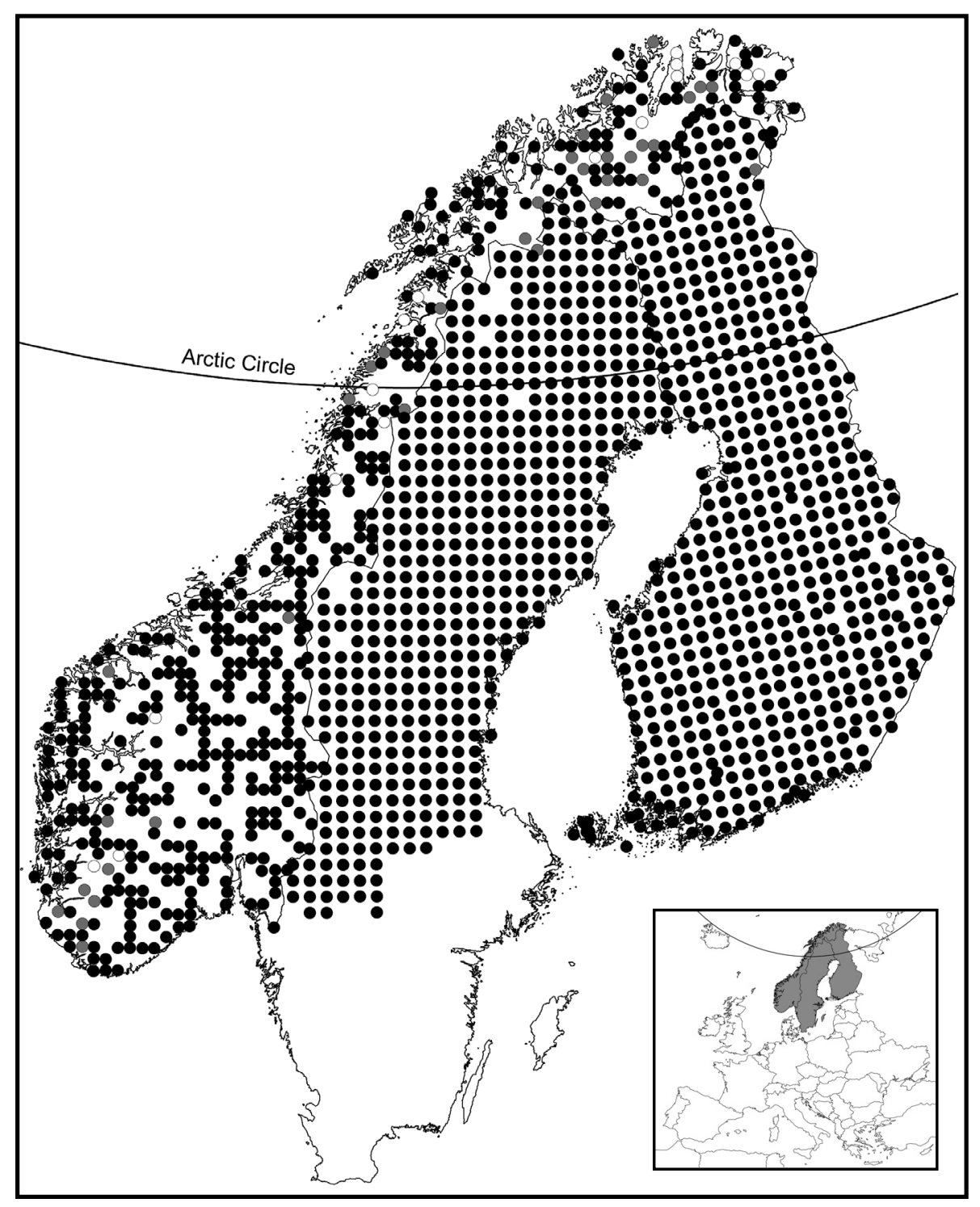

Fig. 1. The black dots show the 1,505 routes that were surveyed at least twice in 2006-2018 and used for estimating population trends. The 34 grey dots are routes surveyed once, which were added to the 1,505 for the analyses of species richness and wader densities. The 17 white dots are routes which have not yet been surveyed. All routes are positioned between $58^{\circ} \mathrm{N}$ and $71^{\circ} \mathrm{N}$, and their distribution largely coincides with the boreal and polar regions of Norway, Sweden and Finland. The Arctic Circle (at $66^{\circ} 34^{\prime} \mathrm{N}$ ) is also shown.

scale and systematic monitoring data from their breeding grounds are hard to come by, mainly due to logistic problems. These include vast and largely inaccessible areas of mires, taiga and tundra, and low densities of observers. Most estimates for northern breeders instead come from outside the breeding grounds, at stopover sites during migration (e.g. Waldenström \& Lindström 2001, Bart et al. 2007, Meltofte \& Claussen 2016) or from their wintering sites (Wetlands International 2012, Simmons et al. 2015, van Roomen et al. 2018). However, the precise location of the breeding grounds of these birds may be poorly known, and estimates of yearly population change may be affected by spatial and temporal variation in migration routes, usage of stopover sites and wintering areas (Ydenberg et al. 2004).
In Fennoscandia (Norway, Sweden and Finland) largescale systematic and representative bird monitoring has been carried out over the last two decades, with hundreds of routes in each country being surveyed each year (Lindström et al. 2015). The routes cover mires, taiga and tundra in direct proportion to their surface area, distribution and characteristics. As far as boreal and arctic waders are concerned, this resulted in a first publication of large-scale population trends based on counts on their breeding grounds. Trends were presented for the period 20022013 , based on 1,263 routes evenly distributed over an area of $\sim 1$ million $\mathrm{km}^{2}$ (Lindström et al. 2015), where the years 2002-2005 were represented by Swedish data only. Since 2013, the Norwegian and Finnish monitoring efforts especially have been intensified, now providing even better coverage of northern-breeding waders in these countries. 
We here present joint Fennoscandian as well as national population trends for 22 species during the period 20062018. For a subset of species, we compare the trends with long-term population trends from other parts of their European breeding area, and trends from the non-breeding season. We also follow up on Lindström et al. (2015) and test whether migratory status (Sanderson et al. 2006) and latitudinal distribution (Jiguet et al. 2010, Laaksonen \& Lehikoinen 2013) may correlate with population trends. Several studies have found that climatic preference roughly coincides with breeding latitude, and that population trends within and between species differ depending on their climatic preferences (e.g. Devictor et al.2008, Jiguet et al. 2010). Our hypotheses are that long-distance migrant waders have declined more than medium-distance migrants, and that population trends of northerly distributed (colddwelling) species are more negative than those of southerly distributed (warm-dwelling) species (Tayleur et al. 2016). Finally, we present some general estimates of how species numbers and total wader densities vary within Fennoscandia. This topic has been addressed before (Järvinen \& Väisänen 1978, Boström \& Nilsson 1983), and can now be revisited some $30-40$ years later with more up-to-date and systematic data. Based on the findings of these earlier studies, we predict that both species richness and overall abundances will increase with latitude.

\section{METHODS}

Our analysis covers the whole of Norway and Finland, and the northern two thirds of Sweden (Fig. 1). All routes included were situated between $58^{\circ} \mathrm{N}$ and $71^{\circ} \mathrm{N}$, which largely coincides with the boreal, montane and arctic regions of Fennoscandia (Ahti et al. 1968).

\section{National monitoring schemes}

Our data originate from three distinct national monitoring schemes that use similar methods to monitor breeding birds of all species. Together the three schemes form a network of 1,556 systematically distributed routes, which are intended to be surveyed once a year in late spring or early summer (Fig. 1). The systematic distribution of these routes ensures that the main habitats in this region are sampled in proportion to the area they cover. All routes are line transects, with some small methodological differences between schemes (see below). In all three schemes, typical survey dates vary between late May in the south and mid-July at the highest latitudes and altitudes. Each survey starts in early morning (04:30 $\pm 1 \mathrm{~h}$, summertime) and lasts about 5-7 hours. We used the sum of birds counted per route as independent data points and, for our trend estimates, only included routes that were surveyed at least twice. Details of the national monitoring schemes are presented in Lindström et al. (2015).

Norway - The monitoring scheme ('TOV-E') started in 2006 and includes 493 sites, randomly selected from a grid of 1,030 sites distributed systematically in an $18 \mathrm{~km}$ north-south and $18 \mathrm{~km}$ east-west network covering the Norwegian mainland (Kålås \& Husby 2002). Generally, birds are counted at $12-20$ points, situated $300 \mathrm{~m}$ apart, forming a $1.5 \mathrm{~km}$ x $1.5 \mathrm{~km}$ square, but with some flexibility to accommodate routes in areas with very challenging topography. Observations of non-passerines, such as waders, are also recorded while the surveyor moves on foot between the counting points, giving a survey route of approximately $6 \mathrm{~km}$. Thus, the census method for waders is very similar to the line transects in Sweden and Finland (see below). The coverage of the survey has gradually and greatly improved since 2013, particularly in the far north of Norway (cf. Lindström et al. 2015).

Sweden - Surveys started in 1996, and are carried out along $8 \mathrm{~km}$ 'fixed routes' that run around the perimeter of $2 \mathrm{~km} \times 2 \mathrm{~km}$ squares (Lindström et al. 2013). There are 497 of these routes in the designated boreal and arctic area, laid out on a regular $25 \mathrm{~km}$ x $25 \mathrm{~km}$ grid running north-south and east-west.

Finland - A countrywide system of 566 systematically distributed fixed line transect routes was established in 2006 (Väisänen 2006). Each route is $6 \mathrm{~km}$ long, and shaped like a $1 \mathrm{~km} \times 2 \mathrm{~km}$ rectangle, with each route centred on the corner of a $25 \mathrm{~km} \mathrm{x} 25 \mathrm{~km}$ grid running north-south and east-west.

In all three countries, the routes are covered by walking and the distance surveyed may differ from the full route length, due to landscape features such as lakes, sea, growing fields, precipices, etc. In Finland and Norway, the birds observed are recorded in units of 'pair equivalents' in the field by the observer. The following observations are treated as one pair: a singing male, a single quiet bird, a male and a female together, and parent(s) with offspring (Koskimies \& Väisänen 1991, Lehikoinen 2013). In Sweden, the survey unit is the number of all adult individuals, independent of behaviour (males as well as females, but not young of the year). Accordingly, Swedish numbers are higher in a direct comparison to Finnish and Norwegian numbers. We have in a previous study shown that these differences do not have any effect on trend estimates (Lehikoinen et al. 2014), and therefore we used the untransformed Swedish numbers in the trend analyses. When comparing wader densities, the Swedish data were converted to pair equivalents (see below).

\section{Analyses}

Population trends - We calculated species-specific population trends using the package rtrim in program $\mathrm{R}$ (Bogaart et al. 2018, R Core Team 2019). Package rtrim is an implementation in $\mathrm{R}$ of the TRIM program (TRends and Indices for Monitoring data; Pannekoek \& van Strien 2004). TRIM is the standard trend analysis tool used in the Pan-European Common Bird Monitoring Scheme (Gregory et al. 2007). The statistical model in TRIM builds on Poisson log-linear regression, estimating site and time (year) effects on species abundance (counts) as well as an overall linear trend (on the log-scale). The basic TRIM model is: expected count = year + site, where both year and site are fixed effects. Effects are estimated using maximum likelihood and generalized estimating 
equations, the latter to handle potential overdispersion and serial (auto) correlation. We used a 'switching trend' model (model 2) in rtrim, which means that time effects are estimated as changes in abundance (on a log-scale) between specified changepoints (Boogart et al. 2018). We specified the inclusion of all possible changepoints (one for each year except the last year) and enabled automatic deletion of changepoints at years with no observations (autodelete $=$ TRUE) and controlled for overdispersion and autocorrelation (overdisp $=$ TRUE, serialcorr $=$ TRUE). In cases where data for a species are available for all years, no changepoints are deleted and a switching trend model estimates changes between each year, making it equivalent to a 'time effects' model (model 3 ). The latter was the case for 19 of the 22 species we present trends for (Appendix 1). In the other three species, one or two changepoints (years) were deleted.

We calculated joint Fennoscandian and country-specific trends and yearly indices for the period 2006-2018. The results presented for Sweden refer to the boreal and arctic parts only. For each species, the index of abundance in 2006 was set to 1 . Species estimates of overdispersion and serial correlation were generally small for the joint Fennoscandian trends (close to 1 and 0, respectively), ranging from 1.11 to 2.46 (overdispersion), and from -0.19 to 0.12 (serial correlation). At the country level, with smaller samples, values ranged from 0.79 to 3.21 (overdispersion), and from -0.31 to 0.14 (serial correlation).

To assess the overall trends of northern wader populations we calculated a multi-species indicator (MSI) according to Gregory et al. (2005), where the index for each year is the geometric mean of the TRIM indices of the contributing bird species. We applied a recently developed Monte Carlo method to account for sampling error in trend estimation in the MSIs. Smoothed trends and 95\% confidence intervals were calculated following Soldaat et al. (2017) using the MSI-tool in $\mathrm{R}$ available at: https://www.cbs.nl/en-gb/society/nature-and-environment/ indices-and-trends-trim-/msi-tool.

We tested whether population trends of species were explained by their migratory behaviour. More specifically we compared population trends of species wintering south of the Sahara or in tropical Asia (long-distance migrants) to those of species wintering within Europe or in North Africa (medium-distance migrants; Fransson et al. 2008) using a $t$-test (wtd.t.test in the package weights in R; Pasek et al. 2018, R Core Team 2019). Furthermore, using a linear model, we tested whether the population trends of species depended on their average breeding latitude. We used the latest Finnish Breeding Bird Atlas to estimate the mean breeding latitude for each species, according to the method of Brommer et al. (2012); the mean breeding latitude in Finland (see Table 1) is a good proxy for the species' north-south distribution in Fennoscandia. Each of the two tests above were also carried out in a variant where we weighted the population trends by the reciprocal of the trend standard error (where a smaller SE gives a higher weight to the trend).
Patterns of wader species richness and breeding densities We analysed patterns of wader species richness and density within boreal and arctic Fennoscandia by calculating these metrics as the number of wader species and the number of wader pair equivalents (per $10 \mathrm{~km}$ ) recorded per survey. We then used the average values per route as the independent data in our statistical analyses. In addition to the routes included in the trend estimates, we here also included routes surveyed only once.

It was difficult to construct fully appropriate statistical models to test how these two variables vary with latitude. Whereas the data for route-specific species richness is close to being normally distributed (mean $3.0, \mathrm{SD}=1.6$, $n=1,539$ ), wader density is not (mean $15.8, \mathrm{SD}=17.0, n$ $=1,539$ ). In addition, the values for wader densities are decimal numbers (due to the conversion of Swedish data into pair equivalents), which precludes the use of GLMM with negative binomial or Poisson error distributions. It is obvious from visual inspection that both variables are strongly and positively correlated with latitude. Since we were mainly interested in the numerical change with latitude, we decided to apply a fairly simple analysis.

We tested the effect of latitude and route length (both fixed factors) on species richness in a linear mixed model (package lme4 in R), with route as a random factor. Route length was included as it varies within and between countries, where the Swedish routes were on average $7.4 \mathrm{~km}$ long, the Norwegian $5.5 \mathrm{~km}$, and the Finnish $6.0 \mathrm{~km}$. The length of a route will clearly affect the number of species likely to be found. For each route we also calculated the mean number of species recorded per route, a value we used for graphical presentation and summary statistics (mean species richness per $1^{\circ}$ latitude).

When estimating wader densities, we needed to take into account some inter-country differences. These included the fact that counts are of individuals in Sweden and of pair equivalents in Norway and Finland, and also that Swedish routes are typically longer than Norwegian and Finnish routes. For each survey in Sweden, we transformed the total number of individuals observed into pair equivalents, using species-specific correction factors based on the Finnish line transect scheme, with counts in Finland, Sweden, Norway, Estonia and Russia, where both the number of individuals and the number of pair equivalents were counted (Table 1). These data have not been published previously, but the method is described in Lehikoinen (2013). When a single individual was observed, a value of 1 was used as 'pair equivalent. However, all counts higher than one were divided by the correction factor (one individual means automatically one pair, but two individuals could mean one or two pairs, and so on). The correction factors range from 1.600 in Purple Sandpiper Calidris maritima to 1.039 in Green Sandpiper Tringa ochropus. By way of example, a value of 2 individuals of Green Sandpiper on a Swedish route was transformed to 1.92 pair equivalents (2 divided by 1.039). This value was then divided by the route-specific transect length and multiplied by 10 . In this way we got a relative 'density' 
Table 1. Population trends (mean annual additive growth rates \pm SE) of 22 wader species recorded in the national monitoring schemes in boreal and arctic Fennoscandia during 2006-2018 (Fig. 1). The trends were calculated using routes surveyed in at least two different years. Significant trends are shown in bold $(P<0.05)$. For example, a growth rate of -0.020 is equivalent to an annual decline of $2.0 \%$ year $^{-1}$. Also shown are the total number of routes (out of the 1,505 routes) where the species was observed at least once, and the total number of encounters (individuals [Swe] or pair equivalents [Nor, Fin]) recorded in 2006-2018. The letter behind the species name codes for migration distance ( $L$ = long-distance migrant, $M=$ medium-distance migrant; see text). The mean breeding latitude in Finland is given at an accuracy of $10 \mathrm{~km}$. We also present the factors used for converting individuals counted in Sweden into pair equivalents (cf. Lehikoinen 2013).

\begin{tabular}{|c|c|c|c|c|c|}
\hline Species & $\begin{array}{l}\text { Population } \\
\text { trend }\end{array}$ & $\begin{array}{l}\text { Routes with } \\
\text { the species }\end{array}$ & Encounters & $\begin{array}{l}\text { Mean breeding } \\
\text { latitude }\left(^{\circ}\right)\end{array}$ & $\begin{array}{l}\text { Conversion factor } \\
\text { (ind } \rightarrow \text { pairs) }\end{array}$ \\
\hline $\begin{array}{l}\text { Oystercatcher } \\
\text { Haematopus ostralegus (M) }\end{array}$ & $0.048 \pm 0.022$ & 103 & 992 & 62.02 & 1.202 \\
\hline $\begin{array}{l}\text { Lapwing } \\
\text { Vanellus vanellus (M) }\end{array}$ & $-0.001 \pm 0.006$ & 310 & 6,490 & 63.01 & 1.330 \\
\hline $\begin{array}{l}\text { Ringed Plover } \\
\text { Charadrius hiaticula (M) }\end{array}$ & $0.020 \pm 0.014$ & 130 & 1,085 & 65.92 & 1.156 \\
\hline $\begin{array}{l}\text { Dotterel } \\
\text { Charadrius morinellus (M) }\end{array}$ & $0.049 \pm 0.027$ & 95 & 598 & 69.14 & 1.164 \\
\hline $\begin{array}{l}\text { Golden Plover } \\
\text { Pluvialis apricaria (M) }\end{array}$ & $0.002 \pm 0.003$ & 605 & 18,756 & 66.21 & 1.084 \\
\hline $\begin{array}{l}\text { Common Snipe } \\
\text { Gallinago gallinago (M) }\end{array}$ & $0.005 \pm 0.004$ & 1,138 & 9,373 & 64.68 & 1.051 \\
\hline $\begin{array}{l}\text { Jack Snipe } \\
\text { Lymnocryptes minimus (M) }\end{array}$ & $0.040 \pm 0.022$ & 111 & 396 & 66.92 & 1.069 \\
\hline $\begin{array}{l}\text { Woodcock } \\
\text { Scolopax rusticola (M) }\end{array}$ & $-0.009 \pm 0.009$ & 590 & 1,376 & 63.13 & 1.055 \\
\hline $\begin{array}{l}\text { Curlew } \\
\text { Numenius arquata (M) }\end{array}$ & $-0.001 \pm 0.004$ & 571 & 6,512 & 63.62 & 1.140 \\
\hline $\begin{array}{l}\text { Whimbrel } \\
\text { Numenius phaeopus (L) }\end{array}$ & $-0.013 \pm 0.006$ & 569 & 5,755 & 66.49 & 1.092 \\
\hline $\begin{array}{l}\text { Green Sandpiper } \\
\text { Tringa ochropus (L) }\end{array}$ & $0.002 \pm 0.004$ & 906 & 7,083 & 63.68 & 1.039 \\
\hline $\begin{array}{l}\text { Wood Sandpiper } \\
\text { Tringa glareola }(\mathrm{L})\end{array}$ & $0.008 \pm 0.003$ & 809 & 16,151 & 65.81 & 1.062 \\
\hline $\begin{array}{l}\text { Common Sandpiper } \\
\text { Actitis hypoleucos (L) }\end{array}$ & $-0.009 \pm 0.006$ & 664 & 3,462 & 64.57 & 1.089 \\
\hline $\begin{array}{l}\text { Redshank } \\
\text { Tringa totanus (M) }\end{array}$ & $0.009 \pm 0.006$ & 416 & 4,834 & 63.55 & 1.121 \\
\hline $\begin{array}{l}\text { Spotted Redshank } \\
\text { Tringa erythropus (L) }\end{array}$ & $-0.028 \pm 0.014$ & 163 & 579 & 67.61 & 1.065 \\
\hline $\begin{array}{l}\text { Greenshank } \\
\text { Tringa nebularia (L) }\end{array}$ & $0.001 \pm 0.004$ & 835 & 7,498 & 65.56 & 1.047 \\
\hline $\begin{array}{l}\text { Purple Sandpiper } \\
\text { Calidris maritima (M) }\end{array}$ & $0.030 \pm 0.040$ & 27 & 201 & 69.30 & 1.600 \\
\hline $\begin{array}{l}\text { Temminck's Stint } \\
\text { Calidris temminckii (L) }\end{array}$ & $-0.024 \pm 0.024$ & 61 & 265 & 68.00 & 1.077 \\
\hline $\begin{array}{l}\text { Dunlin } \\
\text { Calidris a. alpina (M) }\end{array}$ & $0.041 \pm 0.018$ & 79 & 963 & 68.18 & 1.210 \\
\hline $\begin{array}{l}\text { Broad-billed Sandpiper } \\
\text { Calidris falcinellus (L) }\end{array}$ & $-0.056 \pm 0.024$ & 72 & 353 & 67.58 & 1.142 \\
\hline $\begin{array}{l}\text { Ruff } \\
\text { Calidris pugnax (L) }\end{array}$ & $-0.023 \pm 0.025$ & 106 & 472 & 66.63 & 1.353 \\
\hline $\begin{array}{l}\text { Red-necked Phalarope } \\
\text { Phalaropus lobatus (L) }\end{array}$ & $-0.079 \pm 0.022$ & 74 & 482 & 68.30 & 1.348 \\
\hline
\end{tabular}


measure in 'pair equivalents per $10 \mathrm{~km}$ ' for each species and census. We then calculated a total number of wader pair equivalents per census ('wader density'), by summing the species-specific values.

No linear regressions were applied to how wader density varies with latitude (for reasons of non-normality explained above). Instead we calculated the average total wader density per route (pair equivalents per $10 \mathrm{~km}$ line transect), a value we then use for graphical presentation and summary statistics (average wader density per $1^{\circ}$ latitude). For our estimates of wader species richness and pairs per $10 \mathrm{~km}$, we could include information from an additional one Finnish and 33 Norwegian (routes surveyed only once), as compared to our trend estimates.

\section{RESULTS}

\section{Population trends}

In total 9,713 surveys of 1,505 unique routes were included in the trend analyses. Of these, 3,077 surveys of 443 routes were carried out in Norway, 3,788/497 in Sweden, and 2,848/565 in Finland. This means that compared to the previous analysis (data up to 2013; Lindström et al. 2015), information was added from 129 new routes in Norway, one new route in Sweden and 78 new routes in Finland. The number of routes included per year increased from 372 in 2006 to 946 in 2018, with a maximum of 989 in 2017. The survey effort in 2017 corresponds to 6,250 $\mathrm{km}$ of line transects in one year.

In Norway, the routes included were surveyed an average of 6.9 times (range 2-13). The corresponding figures for Sweden and Finland are 7.8 (range 2-13) and 4.9 (range $2-13)$, respectively. Altogether, 93,945 wader encounters (individuals or pair equivalents) of 28 species were recorded, of which 22,744 pairs were in Norway, 41,324 individuals in Sweden and 29,877 pairs in Finland.

The five species recorded in the highest numbers (in order from the highest) were Golden Plover Pluvialis apricaria, Wood Sandpiper T. glareola, Common Snipe Gallinago gallinago, Greenshank T. nebularia and Green Sandpiper. The five most widespread species, seen on the highest number of routes, were Common Snipe, Green Sandpiper, Greenshank, Wood Sandpiper and Common Sandpiper Actitis hypoleucos (Table 1).

We decided to present trends only for species for which, on average, at least 15 encounters have been registered yearly. This leaves us with trends for 22 of the 28 species observed (Table 1, Fig. 2, Appendix 1). For three species, the joint Fennoscandian trends were significantly negative: Red-necked Phalarope Phalaropus lobatus $\left(-7.9 \%\right.$ year $\left.^{-1}\right)$, Broad-billed Sandpiper Calidris falcinellus $\left(-5.4 \%\right.$ year $\left.^{-1}\right)$, and Whimbrel Numenius phaeopus $\left(-1.3 \%\right.$ year $\left.^{-1}\right)$. For three species, the trends were significantly positive: Oystercatcher Haematopus ostralegus $\left(+4.9 \%\right.$ year $\left.^{-1}\right)$, Dunlin Calidris a. alpina $\left(+4.2 \%\right.$ year $\left.^{-1}\right)$ and Wood Sandpiper $\left(+0.8 \%\right.$ year $\left.^{-1}\right)$. For the remaining 16 species, we found no statistically significant trends. Of these, nine were numerically positive and seven were numerically negative (Table 1).

Another six species were observed during the surveys, but there were fewer than 15 encounters per year (Bartailed Godwit Limosa lapponica, on average 7 birds per year on 25 unique routes; Little Ringed Plover Charadrius dubius 6/32; Great Snipe G. media 6/29; Turnstone Arenaria interpres 2/7; Black-tailed Godwit L. limosa 0/3; Little Stint Calidris minuta 0/1).

At the national level, fewer species met this threshold criterion of an annual mean of 15 encounters (Fig. 3, Appendix 1). Among 15 species in Norway, four trends were significantly negative and none were significantly positive. The corresponding figures for Sweden were $18 / 2 / 4$, and for Finland 13/2/4. For several species the trends clearly differed between countries. It is noteworthy that in the five species with significant trends in at least two countries (Lapwing Vanellus vanellus, Golden Plover, Common Snipe, Curlew N. arquata, and Whimbrel), the direction of the trends always differed between those countries (Fig. 3, Appendix 1).

There was no significant trend in the multi-species indicator (i.e. the joint trend for 22 wader species), either for the whole period 2006-2018 $\left(0.00 \pm 0.57[\mathrm{SE}] \%\right.$ year $\left.^{-1}\right)$, or for the last ten years, 2009-2018 $(-0.54 \pm 0.95[\mathrm{SE}] \%$ year ${ }^{-1}$; Fig. 4). Neither was there an overall trend in the arithmetic mean of the Fennoscandian trends of the 22 species $\left(+0.054 \pm 0.67[\mathrm{SE}] \%\right.$ year $\left.^{-1}\right)$.

Of the 22 species, 10 were long-distance migrants and 12 medium-distance migrants. The trends of the mediumdistance migrants were on average more favourable (mean: $+0.019 \pm 0.006$ [SE]) than for the long-distance migrants (mean: $-0.022 \pm 0.009$ [SE]), the difference being statistically significant, both with $\left(t_{21,1}=14.0, P<0.001\right)$ and without weighting the trends by their trend SE $\left(t_{21,2}=14.2, P<\right.$ $0.001)$. The species-specific population trends were not associated with the species' mean breeding latitude, either with or without weighted trend estimates (linear regression with weight, $t_{20}=-0.61, b=-0.14 \pm 0.23$ [SE] (change in population growth rate $/ 1,000 \mathrm{~km}$ change in mean latitude), $P=0.55$; linear regression without weight, $t_{20}=-0.60, b$ $=-0.18 \pm 0.30[\mathrm{SE}], P=0.56)$.

\section{Patterns of species richness and breeding densities}

Wader species richness and the number of pairs per 10 $\mathrm{km}$ were estimated from 9,747 censuses of 1,539 unique routes (Figs. 5-7).

Wader species richness increased significantly with both latitude (slope $=0.22 \pm 0.012$ [SE], $t_{1566,1}=18.8, P<$ 0.001 ) and route length (slope $=0.17 \pm 0.029$ [SE], $t_{2450,5}$ $=5.9, P<0.001$, Fig. $5 \mathrm{a}$ ). Based on the average per route, the mean number of species per route increased from about one at the lowest latitudes, to about four at the highest latitudes (Table 2). Clearly the lowest route-level species diversity was found in southern and southwestern Norway, and the nearby areas of Sweden (the province of Värmland; Fig. 6). 

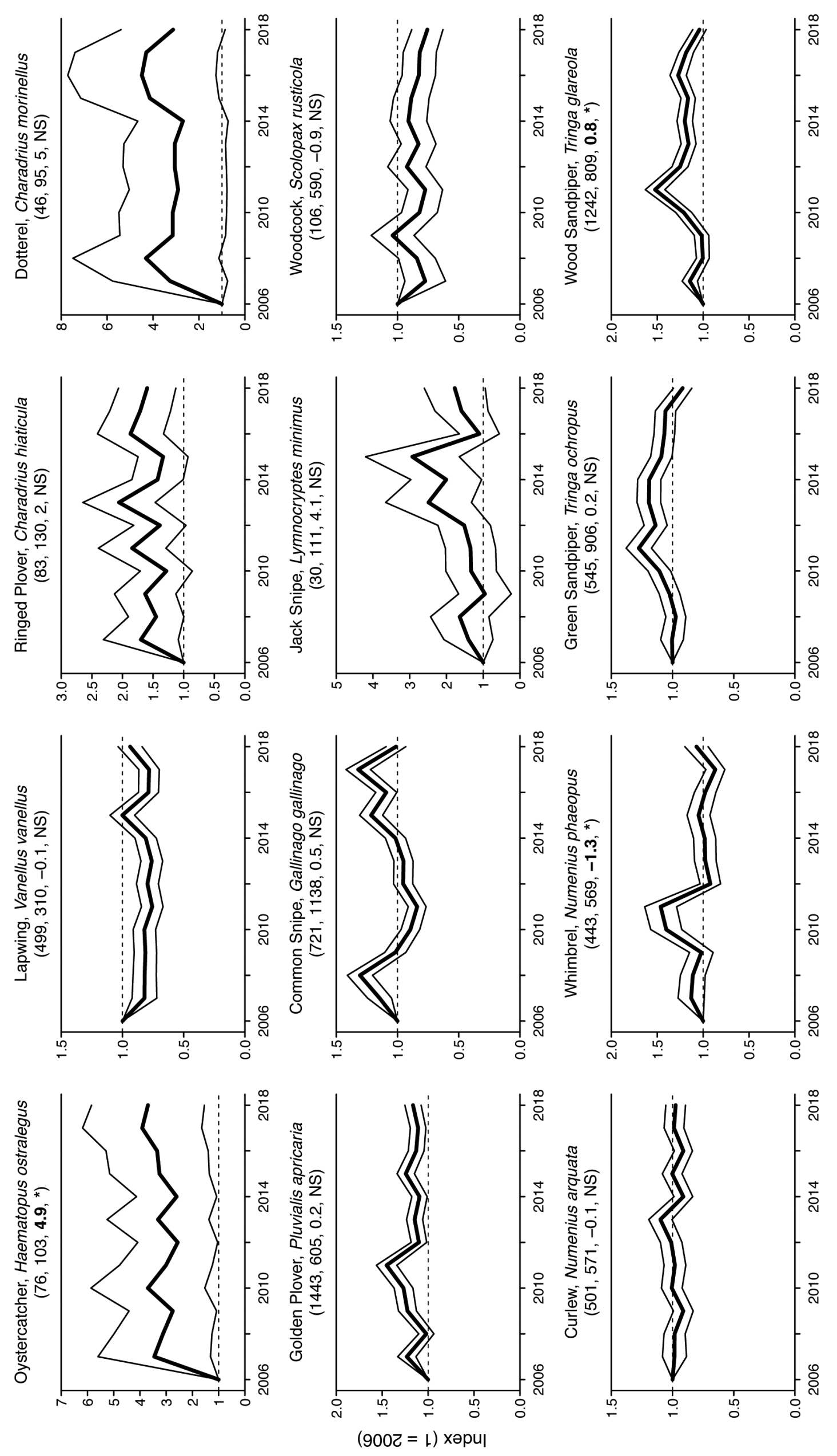


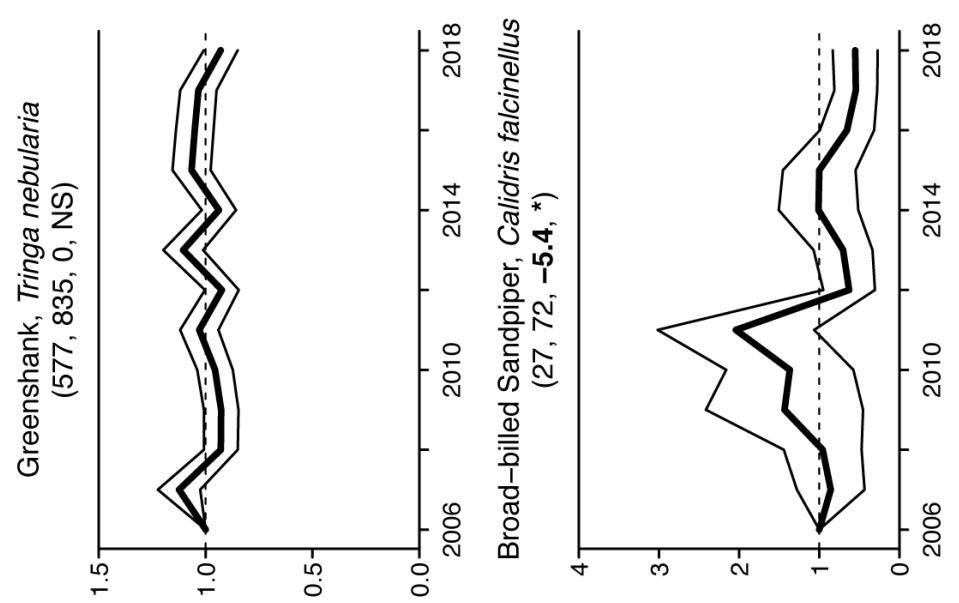

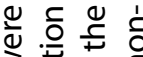

政

ट 융 웡

응응.

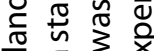

语

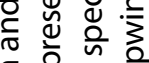

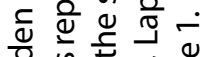

d

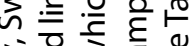

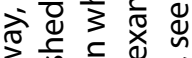

उัज

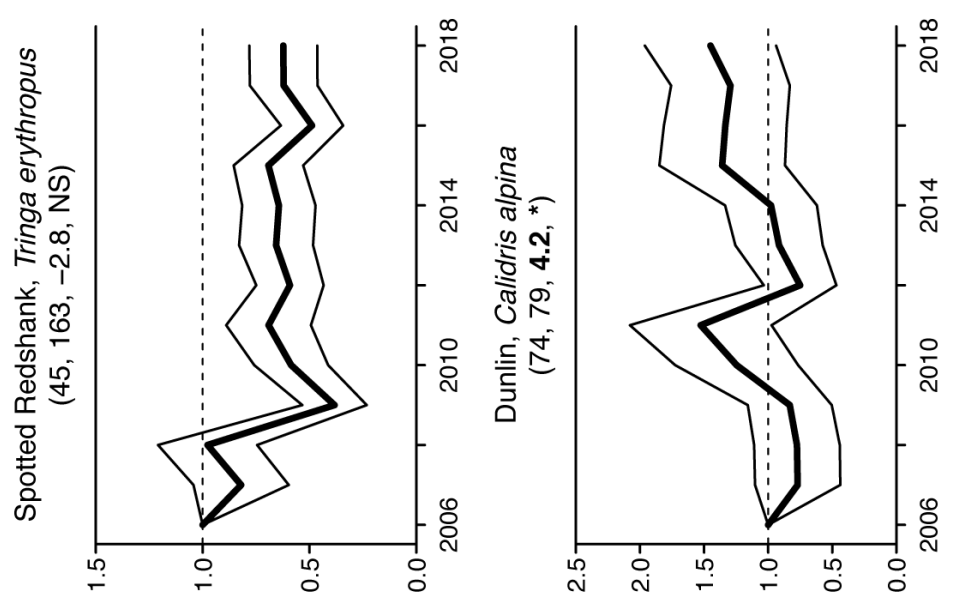

综它

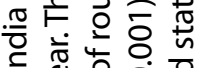

ত

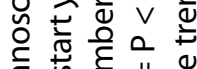

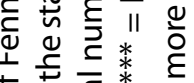

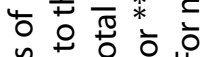

劳

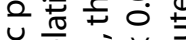

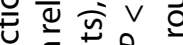

त。 $\subseteq$ व $\|$

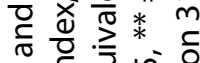

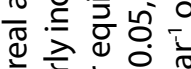

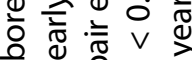

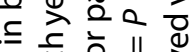
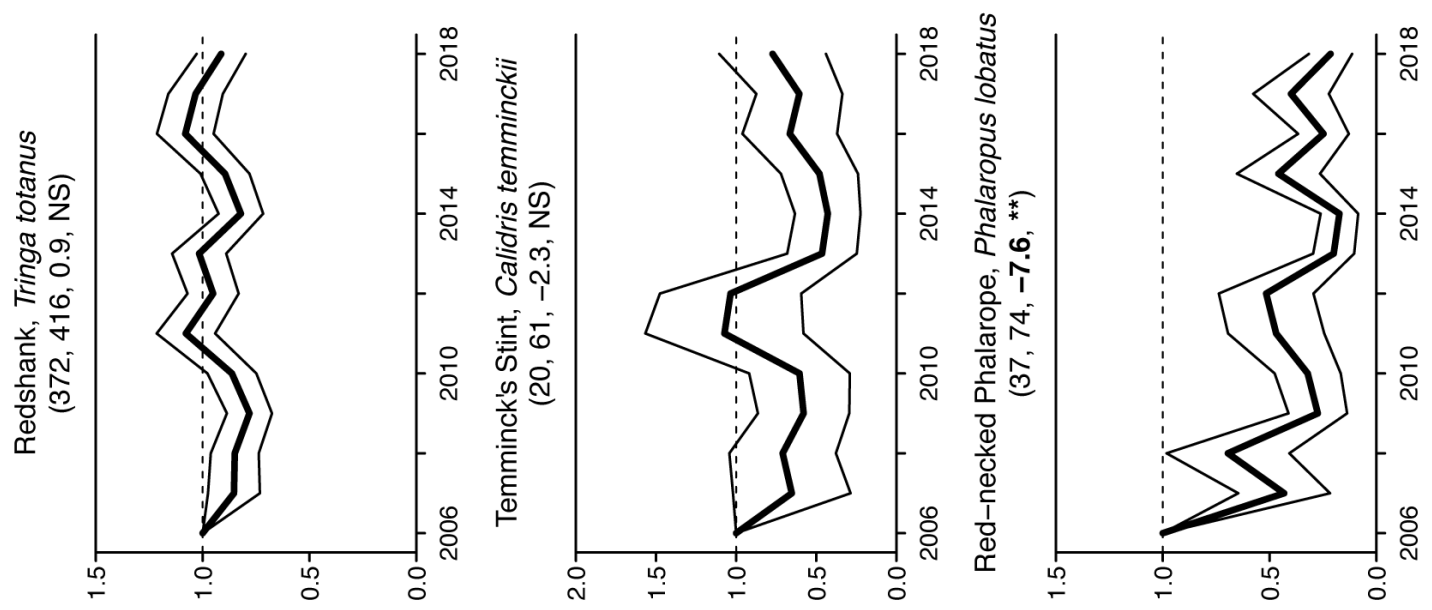

逑

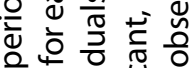

을

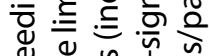

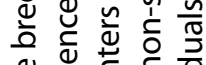

뜬

원

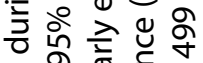

气 ญ

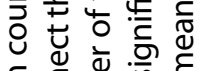

б

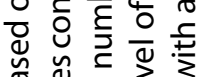

ฮั

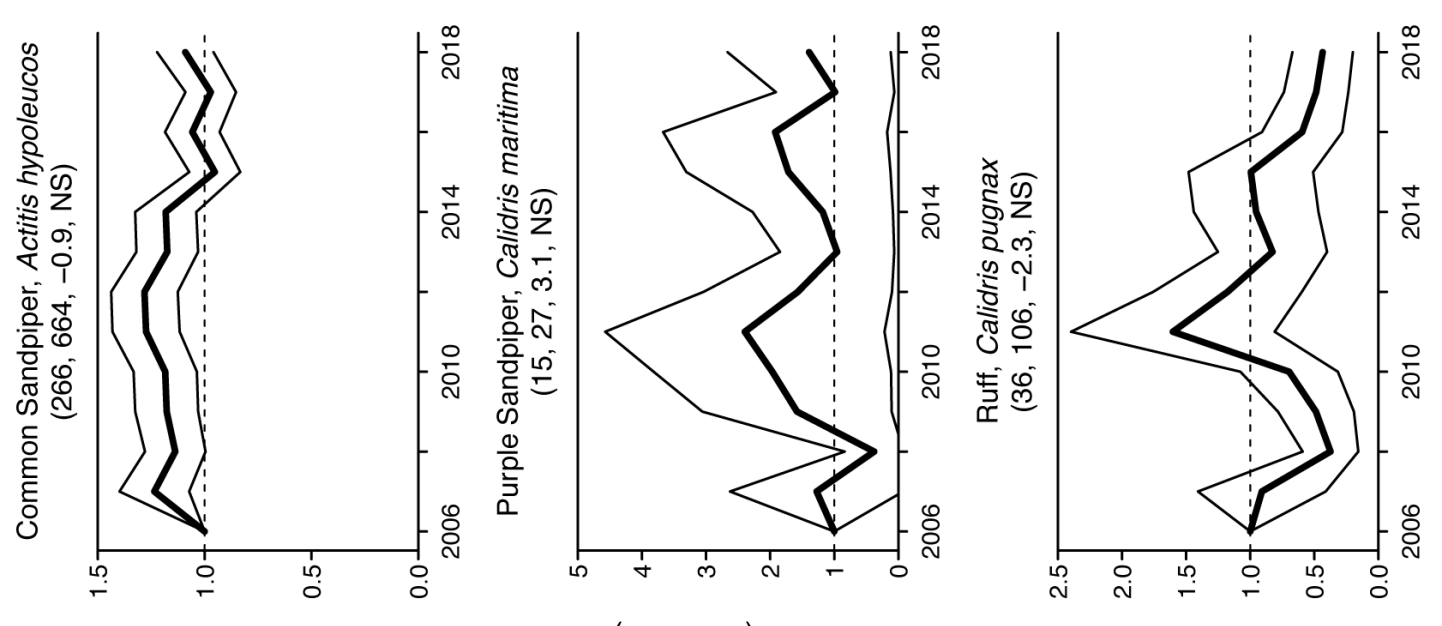

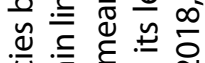

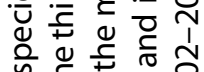

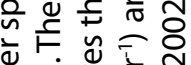

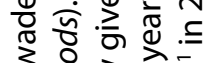

సิ

पे $\sum_{0} \cong \stackrel{0}{\Xi}$

눨

¿

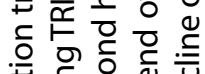

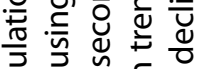

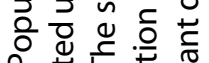

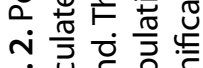

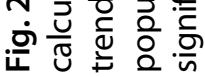


Based on route-specific averages, the median number of wader pairs per $10 \mathrm{~km}$ increased from just below three at latitudes $58-60^{\circ} \mathrm{N}$, to just above 26 at latitudes $69-71^{\circ} \mathrm{N}$ (Table 2, Fig. 5b). The highest densities of waders were found in northernmost Norway and Finland, but also along the northern two thirds of the Scandinavian mountain range (Fig. 7).

\section{DISCUSSION}

\section{Waders in boreal and arctic Fennoscandia}

The trends we present represent a range of European species, for which the proportion of their populations held by boreal and arctic Fennoscandia varies widely. Some of the species covered in this analysis are exclusively boreal- and arctic-breeding, such as Temminck's Stint Calidris temminckii, Purple Sandpiper, Broad-billed Sandpiper and Spotted Redshank T. erythropus. Other species, such as Ringed Plover Charadrius hiaticula, Golden Plover, Dunlin and Redshank T. totanus, have large populations in boreal and arctic Fennoscandia, particularly in the Scandinavian Mountains, but also substantial populations further south in Europe at both inland and coastal sites. Some species, such as Oystercatcher and Lapwing, have most of their European distribution south of boreal/arctic
Fennoscandia. One should also bear in mind that boreal and arctic areas in European Russia hold large populations of many of the species considered here (Lappo et al. 2012) and population trends between these areas and Fennoscandia may differ.

\section{Population trends overall}

In contrast with the analysis of Lindström et al. (2015), we left out the first four years of data (2002-2005), which were from Sweden only. Given that trends for some species can differ between countries (Fig. 3, Appendix 1), restricting the analysis to a period during which all three countries were contributing data should make the joint trends more robust. At the same time, five more years were added to the time series. Accordingly, only eight (2006-2013) of the 17 years (2002-2018) under scrutiny are the same in the two analyses (Lindström et al. 2015), which opens up the potential for differences in the speciesspecific trends between the two time periods.

Nevertheless, the wader trends overall did not change much between the analyses of Lindström et al. (2015) and those presented here. As during 2002-2013, there was no overall general direction of the trends during 2006-2018 (Figs. 2 \& 4), and similar numbers of species had significantly negative and significantly positive trends in the two

Table 2. Average species richness (species per route) and wader pair density (pairs per $10 \mathrm{~km}$ line transects) per degree latitude on census routes in boreal and arctic Fennoscandia in 2006-2018 (see also Figs. 5-7). Each of the 1,539 routes surveyed at least once is represented by its mean value for the years it was surveyed. Given that wader pair densities are highly skewed towards low values, the median is also presented.

\begin{tabular}{|c|c|c|c|c|c|c|}
\hline \multirow{2}{*}{$\begin{array}{l}\text { Latitude } \\
{ }^{\circ} \mathrm{N}\end{array}$} & \multicolumn{2}{|c|}{ Species per route } & \multicolumn{3}{|c|}{ Pairs per 10 km } & \multirow{2}{*}{$n$ routes } \\
\hline & Mean & SD & Median & Mean & SD & \\
\hline $58-59$ & 1.24 & 0.93 & 2.55 & 4.73 & 8.76 & 31 \\
\hline $59-60$ & 1.33 & 0.86 & 2.88 & 4.52 & 5.77 & 82 \\
\hline $60-61$ & 1.99 & 1.17 & 5.20 & 8.03 & 8.65 & 176 \\
\hline $61-62$ & 2.23 & 1.04 & 6.67 & 8.56 & 7.02 & 181 \\
\hline $62-63$ & 3.03 & 1.39 & 9.82 & 15.44 & 16.19 & 210 \\
\hline $63-64$ & 3.28 & 1.42 & 10.57 & 15.92 & 14.45 & 157 \\
\hline $64-65$ & 3.54 & 1.37 & 10.42 & 14.78 & 12.17 & 141 \\
\hline $65-66$ & 3.47 & 1.43 & 12.72 & 16.94 & 15.13 & 128 \\
\hline $66-67$ & 3.25 & 1.23 & 12.61 & 15.71 & 11.64 & 123 \\
\hline $67-68$ & 3.38 & 1.26 & 17.91 & 22.38 & 17.43 & 112 \\
\hline $68-69$ & 3.89 & 1.78 & 24.20 & 28.05 & 21.52 & 84 \\
\hline $69-70$ & 4.16 & 2.02 & 26.30 & 35.90 & 30.11 & 81 \\
\hline 70-71 & 3.86 & 2.54 & 26.11 & 33.00 & 25.67 & 33 \\
\hline Sum & 2.97 & 1.59 & 9.81 & 15.77 & 17.00 & 1,539 \\
\hline
\end{tabular}



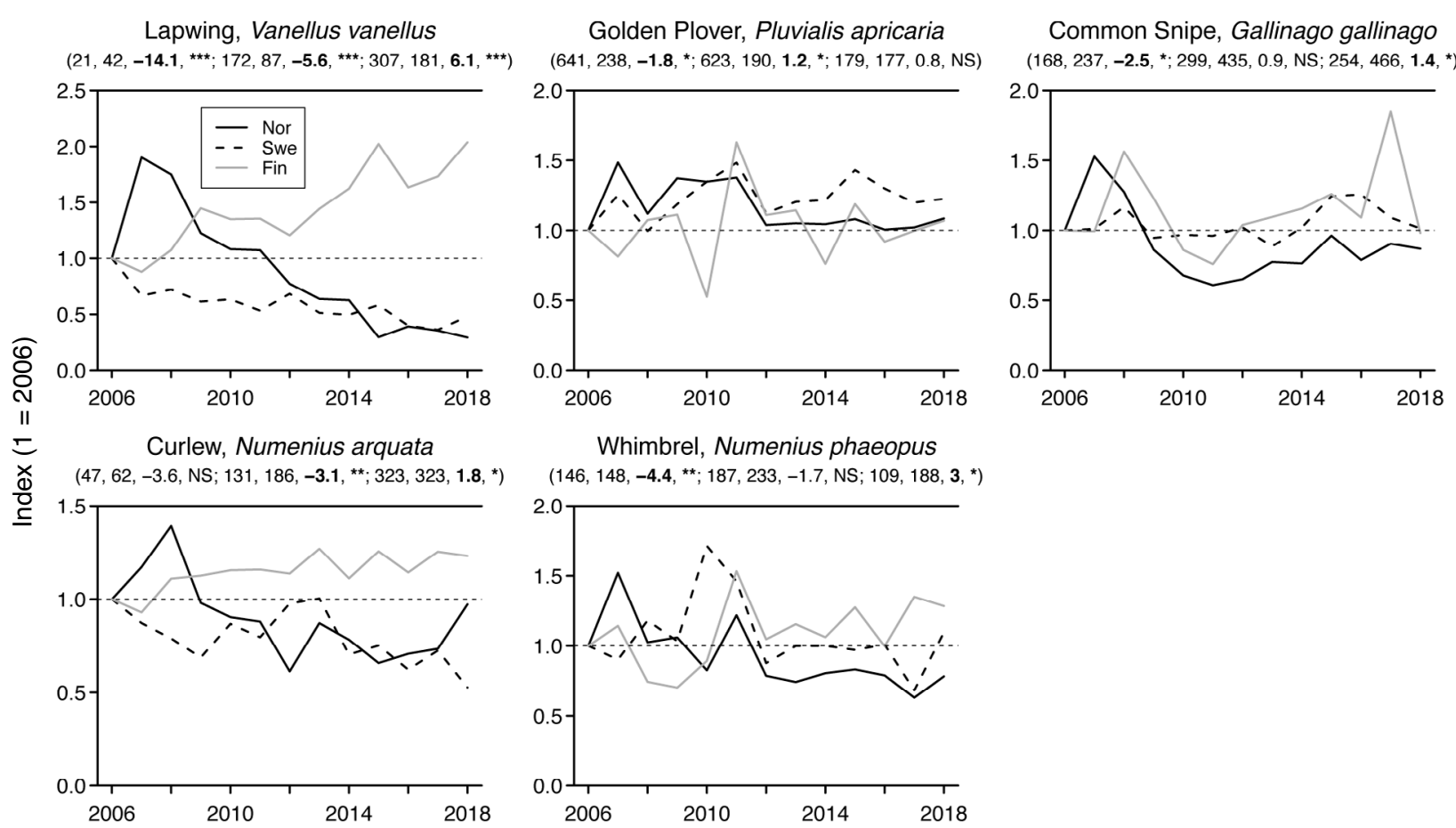

Whimbrel, Numenius phaeopus $\left(146,148,-4.4\right.$, ${ }^{*} ; 187,233,-1.7$, NS; $\left.109,188,3,{ }^{*}\right)$

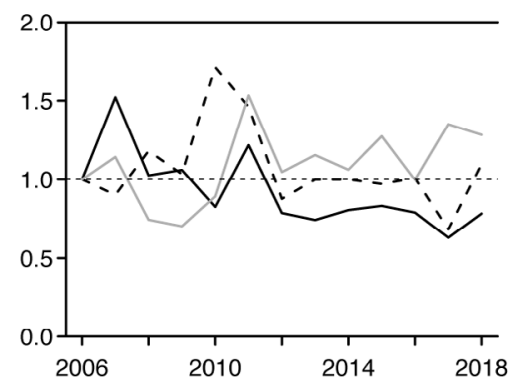

Fig. 3. Country-specific species trends for some common wader species present in all three countries. The dashed lines represent a stable population. The second headline row gives the mean number of yearly encounters (individuals or pair equivalents), the total number of routes on which the species was observed, the population trend over time $\left(\%\right.$ year ${ }^{-1}$ ) and its level of significance (NS, ${ }^{*},{ }^{*}$, or $\left.{ }^{* *}\right)$. These data are given for Norway, Sweden and Finland, with the information separated by semicolons. For more national trends, see Appendix 1.

periods. However, at the species level, some changes are apparent. In the four species with significant increases in 2002-2013, all trends were also numerically positive in 2006-2018, but only Wood Sandpiper was still significantly positive. In the three species with significant decreases in 2002-2013, none were significant in 2006-2018, and for Common Snipe, the trend was now numerically (though non-significantly) positive. Of the six species having significant trends in 2006-2018, three actually had a (nonsignificant) trend in the opposite direction in 2002-2013.

Overall, we can conclude that the power of our monitoring data is strong enough to be able to detect significant changes as small as $0.8 \%$ year $^{-1}$ (Wood Sandpiper). But clearly, the direction and magnitude of species-specific trends can change over relatively short periods, affecting both trend direction and significance level. In any case, the trends estimated for 2006-2018 should be more robust than those for 2002-2013, due to more routes being surveyed yearly and a more balanced design (northern Norway in particular was better covered).

Neither of our two measures of average population trends in northern-breeding waders in Fennoscandia in 20062018, the MSI and the trend average, suggested any general trend in wader numbers. Overall, we concluded that according to our three national monitoring schemes, waders breeding in the boreal and arctic parts of Fennoscandia have fared reasonably well in 2006-2018. In a recent analysis based on long-term migration counts in Denmark
(1928-2014), Meltofte \& Clausen (2016) drew a similar general conclusion for arctic and boreal wader populations passing through Denmark, both in the long and short term (2000-2014), the latter period largely coinciding with the study periods of Lindström et al. (2015) and this study. This does not, of course, preclude there being other species and populations of breeding waders in northern Fennoscandia that are of conservation concern.

\section{Trends in relation to migration distance and breeding latitude}

Among common European birds, especially passerines, recent population declines have been especially severe in long-distance migrants (Sanderson et al. 2006, Gregory et al. 2007). In our previous analysis of the period 20022013, we found no effect of migration distance on population trend (Lindström et al. 2015). During the period 2006-2018, however, the population trends of long-distance migrants were significantly more negative than those of other species. This may indicate increasing problems among long-distance migratory species. One possible problem is a decrease in the quality of wintering and stopover sites in tropical wintering areas. In a recent global analysis of waterbird population trends, based on counts in January-February, wader population trends were on average clearly more positive in Europe than in Africa (Amano et al. 2018). The authors linked the global patterns of population trends to the effectiveness of conservation governance, 'defined as how effectively the authorities of 


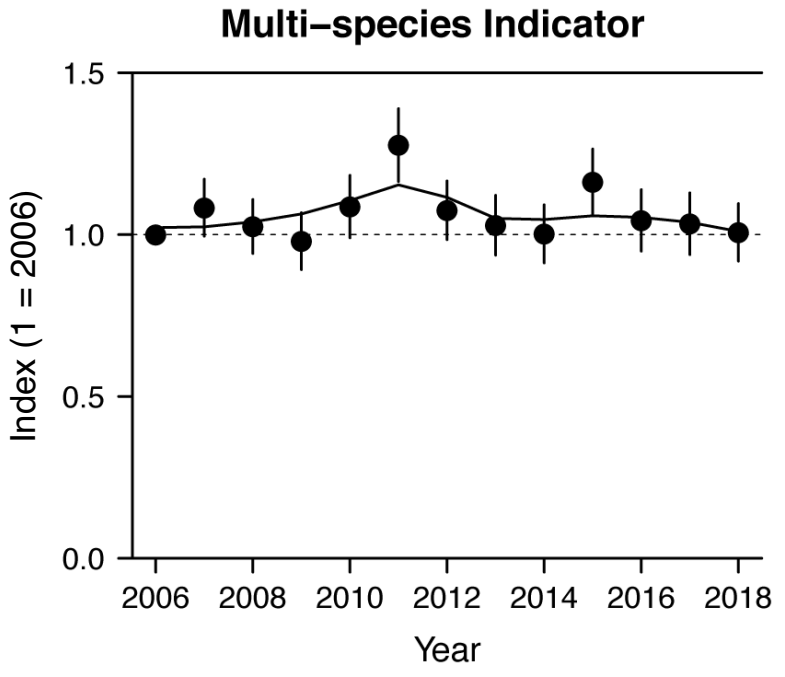

Fig. 4. A multi-species indicator of 22 wader species breeding in boreal and arctic Fennoscandia (species listed in Table 1). The black dots show yearly indices \pm SD (with the first year index set to 1). The solid line is the smoothed trend over time. The dashed line represents a stable population. There was no significant change in the yearly indices over time (see text).
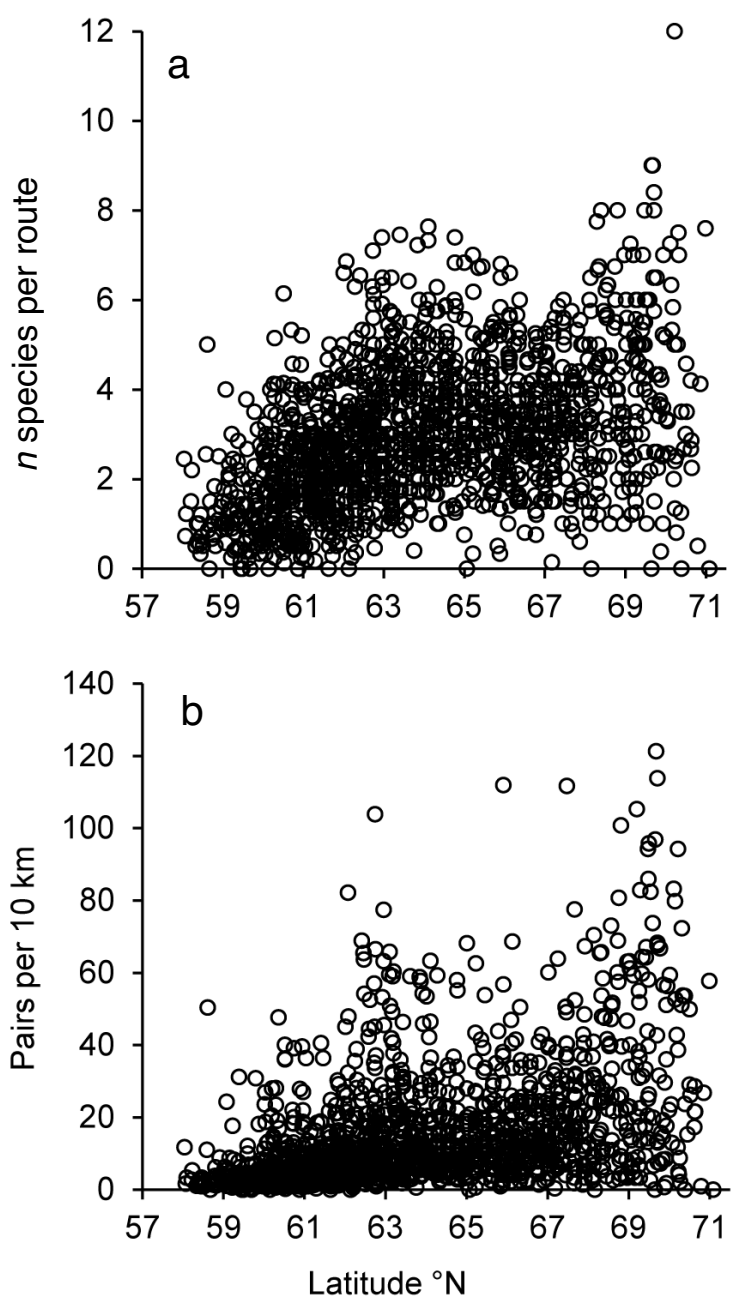

Fig. 5. The mean number of (a) wader species per route, and (b) wader pair equivalents recorded per $10 \mathrm{~km}$ survey, in relation to latitude. Included are 1,539 routes surveyed 1-13 times in 2006-2018. a country exercise rules and enforcement mechanisms' for wetland conservation. Amano et al. (2018) identified sub-Saharan Africa, where most European long-distance migrants over-winter (Fransson et al. 2008), as an area where conservation governance is often ineffective.

Another potential reason for the less favourable trends in long-distance migrants may relate to climate change on the breeding grounds and the inflexibility of migration schedules. Gunnarsson \& Tómasson (2011) found that in Iceland, five wader species wintering in NW Europe had adapted their arrival to changing spring weather, whereas Whimbrel (wintering in Africa) did not. This effect of migration distance on arrival timing was true also for a larger set of migrant species (Gunnarsson \& Tómasson 2011). A lack of response in migration phenology has been shown to correlate with less favourable population trends in migrants (Møller et al. 2008, Franks et al. 2018). However, given that a lack of phenological response can arise from poor staging conditions along the migration route (Tøttrup et al. 2012), and given that a poor phenological response may not necessarily be correlated to poor breeding productivity (Franks et al. 2018), conditions at the staging grounds could themselves be the cause of population decline. Indeed, in taymyrensis Bar-tailed Godwits migrating via the Wadden Sea to the Russian Arctic, it seems as if the need for the godwits to shorten the crucial fuelling period in order to arrive at the breeding grounds in time has led to lower adult survival and a population decline (Rakhimberdiev et al. 2018)

Several studies have found that climatic preference roughly coincides with breeding latitude and that population trends within and between species differ depending on their climatic preferences (e.g. Devictor et al.2008, Jiguet et al. 2010). At least in northern Europe, the recent population trends of species that inhabit more southerly, warmer areas have been more positive than those of northerly, cold-dwelling species (Lindström et al. 2013, Tayleur et al. 2016). We might therefore have expected that the mean breeding latitude of the wader species in this study would be related to their population trend, but this was not the case. The relationship between latitude and climate in northern Fennoscandia is somewhat complicated by the position of the Scandinavian Mountains, which creates a strong altitudinal west-east climate gradient (one on each side), perpendicular to the latitudinal gradient. In addition, within the mountain range, May and June temperatures have not increased during our study period, but July temperatures have (Lehikoinen et al. 2014, Ram et al. 2019), making the potential effects of temperature difficult to predict.

\section{Species-specific population trends}

Whereas our primary aim was to show the overall situation for the boreal and arctic breeding waders in Fennoscandia, some species merit some comments and comparisons with trends from elsewhere. Pan-European population trends from the breeding season are available for 13 of our 22 species (EBCC/BirdLife/RSPB/CSO 2019), for the 


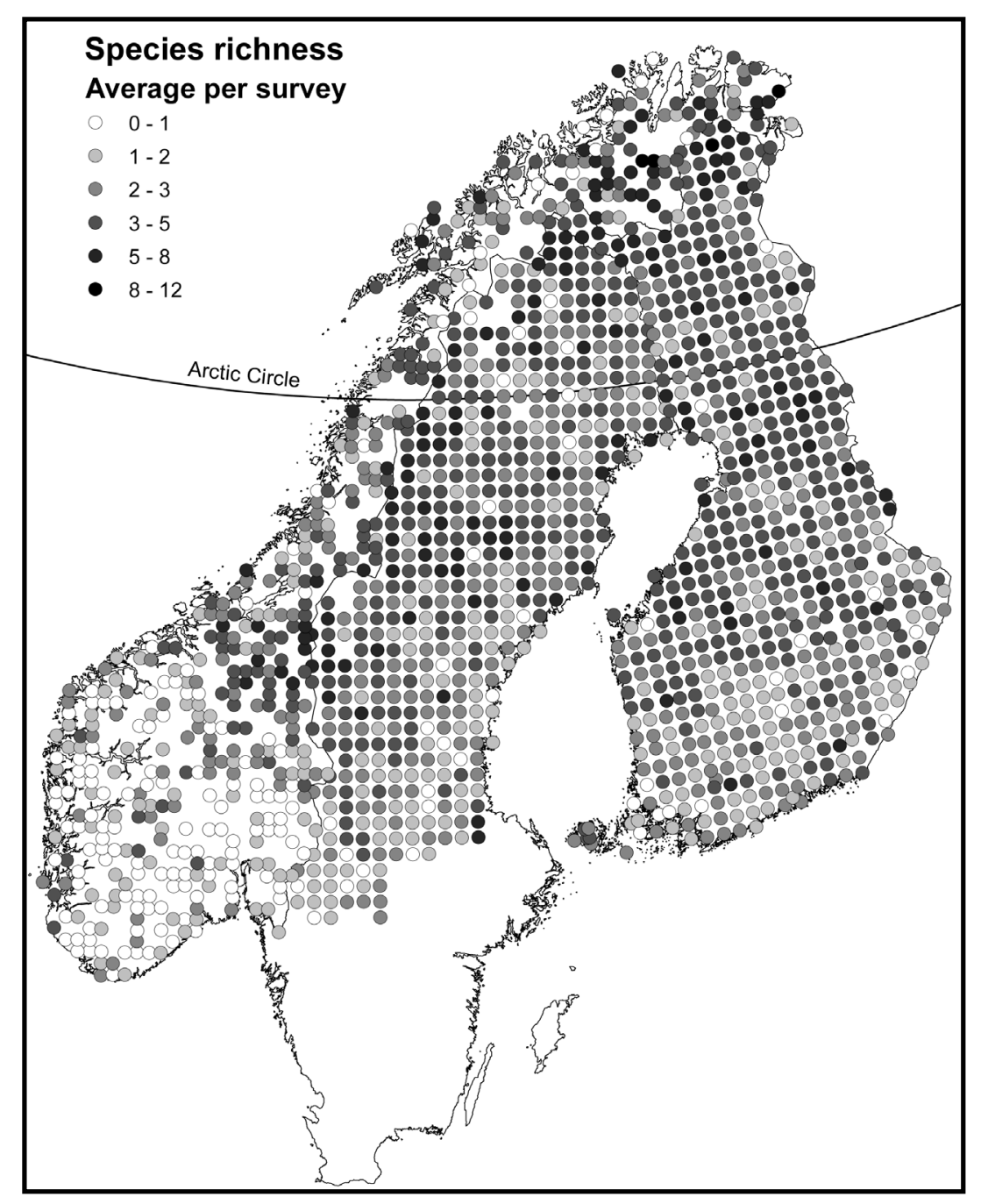

Fig. 6. The mean number of wader species recorded per survey and route in 2006-2018. Data come from 1,539 routes surveyed 1-13 times. Data have not been corrected for variation in mean route length among the countries (Norway $5.5 \mathrm{~km}$, Sweden $7.4 \mathrm{~km}$ and Finland $6.0 \mathrm{~km}$ ). Hence, the species richness is most likely somewhat underestimated in Norway and Finland compared to Sweden (with the longest routes). Within countries the data should be directly comparable. The range ' $0-1$ ' includes exactly 1 , the range' $1-2$ ' starts on 1.00001 and includes exactly 2 , and so on.

periods 1980-2015 and 2006-2015. In all cases these trend estimates include data from Norway, northern Sweden and Finland, which makes them only partially independent from the trends reported here. For other species, the best available data for comparison come from the winter counts of the International Waterbird Census (Wetlands International 2017, 2019, van Roomen et al. 2018), reporting both long-term trends and more recent periods such as 2000-2012 and 2006-2015. These two sources will be referred to as 'European breeding trends' and 'winter trends', respectively, and the various 10-15 year periods from the 2000 s will be referred to as 'recent'.

Oystercatcher - This is one of three species with a significant increase $\left(+4.8 \%\right.$ year $\left.^{-1}\right)$, most of the data deriving from Norway (for details of the presence in Norway, see Heggøy 2018). It should be noted, however, that this increase is only marginally significant and is concentrated during the first year of the trend, when the sample size was at its lowest. Nevertheless, the picture is more favourable than for the wider European breeding population, which has been declining for a long time and recently decreased by $28 \%$. The recent winter trends for the population of NW Europe suggest a stable or possibly declining population.

Lapwing - The overall population in northern Fennoscandia was markedly stable during 2006-2018. European counts of breeding birds suggest a decline of $50 \%$ in this species' population since 1980, with recent trends in both breeding and winter numbers remaining negative. The birds counted in our schemes breed mainly in agricultural areas (coastal and inland) with some also breeding on mires (Ottosson et al. 2012). What is especially remarkable, however, is that the trends within the three Fennoscandian countries are dramatically different (Fig. 3, Appendix 1). In Norway there has been a dramatic decline $\left(-15.2 \%\right.$ year $^{-1}$ during 2006-2018) and the Lapwing is now nearly extinct in many areas. The trend in Sweden is also significantly 


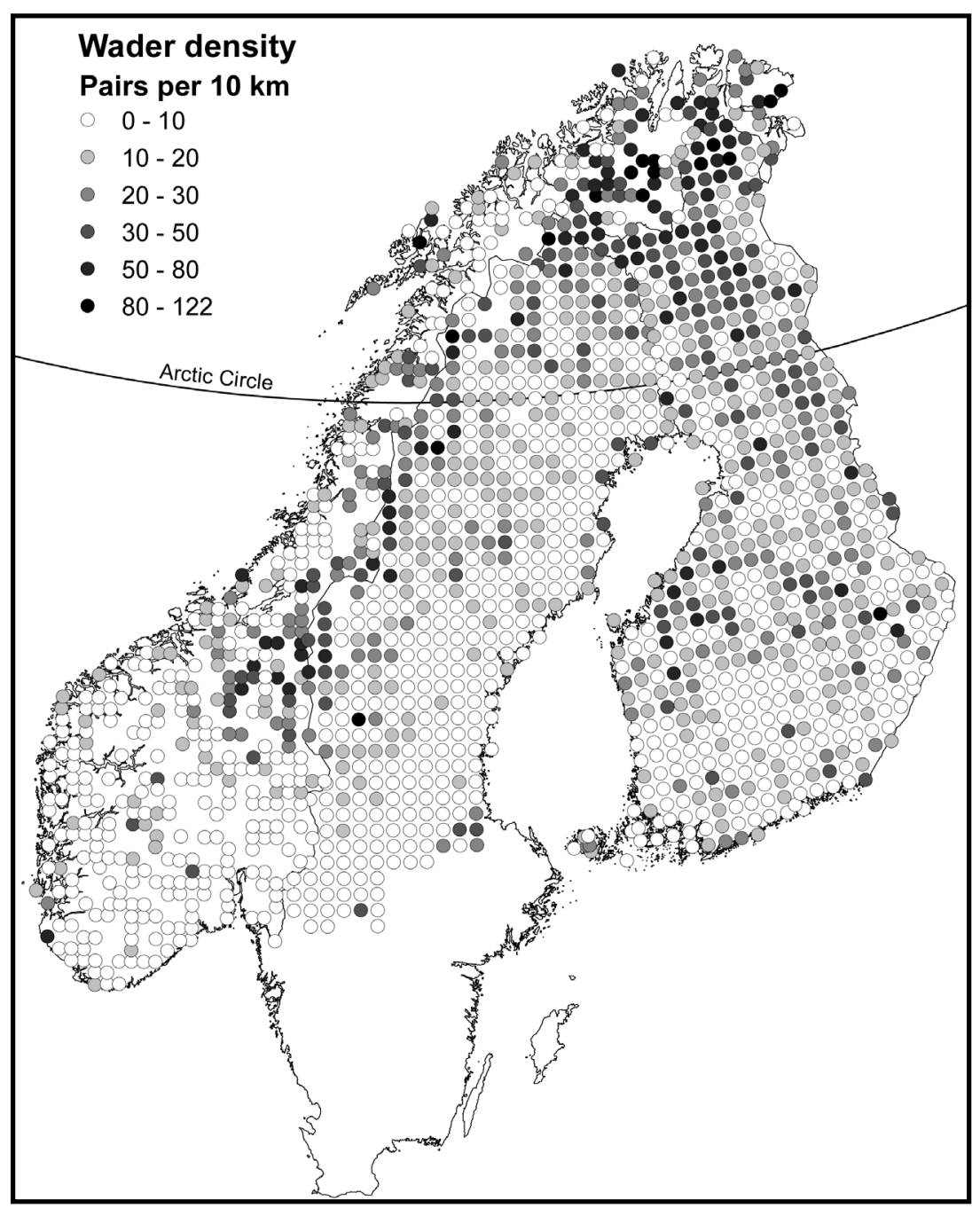

Fig. 7. The mean number of wader pair equivalents (see text) recorded per survey and route in 2006-2018. Data come from 1,539 routes surveyed $1-13$ times, and the unit is wader pair equivalents per $10 \mathrm{~km}$ line transect. The range '0-10' includes exactly 10 , the range' $10-20$ ' starts on 10.00001 and includes exactly 20 , and so on.

negative $\left(-5.8 \%\right.$ year $\left.^{-1}\right)$. In Finland, however, where the species is more widespread and numerous, there has been a strong increase $\left(+5.9 \%\right.$ year $\left.^{-1}\right)$ during the same period, which counters the declines in Norway and Sweden. We have no explanation for these inter-country differences, but the same pattern is also apparent for populations of Curlew and Whimbrel (see below).

Golden Plover - The majority of the large, north Fennoscandian population breeds on tundra in the Scandinavian Mountains, with some smaller numbers also on mires at lower altitudes, and is doing well. There are some country-specific differences in trends (Fig. 3), with a moderate decline in Norway $\left(-1.8 \%\right.$ year $\left.^{-1}\right)$ being countered by a moderate increase in Sweden $\left(+1.2 \%\right.$ year $\left.^{-1}\right)$.

Common Snipe - The overall trend of this species follows a similar pattern in each country (Fig. 3), with an initial decline followed by an increase. Common Snipe has declined as a breeding bird over much of Europe, though European and West African winter numbers seem to be stable.
Jack Snipe - It is rewarding to be able to produce a breeding season trend for this cryptic species, which inhabits very wet mires in some of the most inaccessible areas in northern Europe. On average 30 birds were reported per year, from a total of 111 routes (most of them in Finland). There is no statistically significant change in the Fennoscandian breeding population size. Also the recent European and West African winter trends are reported to be stable.

Woodcock - This is probably the most common breeding wader in Fennoscandia (it is the most common species in Sweden; Ottosson et al. 2012). Despite the fact that there are no surveys carried out during the display period at dusk, enough birds are flushed during line transects to estimate a population trend. The trend for 2006-2018 is basically stable and similar in all three countries. Recent European winter trends are also stable.

Curlew - The overall population curve shows no significant trend. Since 1980 the European breeding trend has shown a total decline of $40 \%$. The populations in Norway and 
Sweden have also declined, but numbers in Finland have increased, just as for Lapwing (Fig. 3). Recent winter trends show a clear decline.

Whimbrel - This is one of three significantly declining species in our analysis $\left(-1.3 \%\right.$ year $\left.^{-1}\right)$. The species breeds on mires, in forest clear cuts, and on mountain tundra. Similarly to Lapwing and Curlew, this species is doing poorly in Norway and Sweden but well in Finland (Fig. 3). Recent West African winter trends are reported to have been stable or increasing.

Wood Sandpiper - One of three significantly increasing species, it is the second most numerous species in our dataset and although its population has increased slowly $\left(+0.8 \%\right.$ year $\left.^{-1}\right)$ this increase is statistically significant. This overall trend is largely driven by Norwegian and Swedish populations, with numbers in Finland remaining relatively stable. In contrast to the recent increase in northern Fennoscandia, there was a $1 \%$ year $^{-1}$ decline in Finland 1981-2014 (Fraixedas et al. 2017). Recent African winter trends are considered stable.

Redshank - The trend for northern Fennoscandia shows no significant direction. The vast majority of the birds are found in Norway and Sweden where they breed along the coasts and in the Scandinavian Mountains. The longterm European breeding trend shows a drop of $56 \%$ and the drop in recent times is $12 \%$ (these data include Norway, Sweden and Finland, but also seven more southern countries). Apparently the boreal and arctic populations fare much better than the breeding populations further south in Europe, in accordance with the climate-based predictions of Huntley et al. (2007).

Broad-billed Sandpiper - This species has the second most negative trend among the 22 species $\left(-5.6 \%\right.$ year $\left.^{-1}\right)$. The bulk of information comes from Finland where the trend is even more negative $\left(-7.5 \%\right.$ year $\left.^{-1}\right)$. There are no good data on winter trends.

Dunlin - Two subspecies (alpina and schinzii) breed in the investigated area, but all birds recorded were found at breeding sites in the Scandinavian Mountains and hence belong to the alpina subspecies. The overall trend is significantly positive $\left(+4.1 \%\right.$ year $\left.{ }^{-1}\right)$, which is in sharp contrast to the strong declines of the schinzii subspecies that breeds around the Baltic Sea and extends into western Finland (Pakanen \& Thorup 2016). The recent European and NW African winter trend for the alpina subspecies is a decline.

Ruff - In our first joint trend analysis (Lindström et al. 2015), the population decline of this species was greater than that of any other. However, the main decline took place in 2002-2005. For the current period, 2006-2018, the trend remains negative $\left(-2.3 \%\right.$ year $\left.{ }^{-1}\right)$, but is not significant. The species has experienced habitat loss in both its breeding and wintering grounds including drainage of mires (Fraixedas et al. 2017) and loss of coastal meadows due to lack of grazing (Valkama et al. 2011), as well as reduced rainfall in wintering areas, which may have negatively affected survival (Zwarts et al. 2009). The West African winter trend is supposedly decreasing.
Red-necked Phalarope - This species has the most negative trend of all the 22 species, with most data coming from Sweden. We do not know the cause of this decline, but given that this species shares its south-eastern migration route with Broad-billed Sandpiper, whose population exhibits the second largest decline (Fransson et al. 2008, van Bemmelen et al. 2016), the relevant problems might largely apply somewhere along the migration routes.

\section{Patterns of species richness and breeding densities}

Both the densities of wader species and wader pairs breeding in Fennoscandia were positively related to latitude. Similar patterns have been reported over several decades for global wader populations as well as those in Fennoscandia (Järvinen \& Väisänen 1978, Boström \& Nilsson 1983, Kuoki 1999). These patterns run counter to the biogeographical rule that species richness decreases towards the poles (e.g. Kouki 1999). Possible reasons for this pattern include habitat heterogeneity at high latitudes, higher availability of preferred prey (i.e. insects), and the likelihood that waders evolved in the Arctic (Johansen 1958, Järvinen \& Väisänen 1978).

Järvinen \& Väisänen (1978) reported on the number of wader species and wader pairs breeding in $100 \mathrm{~km}$ squares in Fennoscandia in general, and Finland in particular. Their data for Fennoscandia are not directly comparable to ours, but large-scale patterns can still be compared. Whereas these authors reported a doubling of local species richness from south to north, our census data suggest an increase by a factor of four. The most obvious difference between these two datasets is that we find fewer species in southern Norway than were reported in the distribution maps used by Järvinen \& Väisänen (1978). The most likely reason for this discrepancy is the generally low density of waders found in southern Norway, for which the chance of detecting most of the species present in the wider landscape ( $c f$. Järvinen \& Väisänen 1978) is greater than it is for a single transect in this study. From line transects carried out in Finland, Järvinen \& Väisänen (1978) found that total wader densities increased roughly two- to three-fold from south to north, whereas we found an approximately eight-fold increase.

\section{ACKNOWLEDGEMENTS}

We are most grateful to the many hundreds of people who censused birds in Norway, Sweden and Finland, and Roald Vang for taking the main responsibility for the TOV-E webpage and database. We thank Mark Wilson, Lilja Jóhannesdóttir, and Samantha Franks for constructive comments on the manuscript. The Norwegian Climate and Environment Ministry and the Norwegian Environment Agency finances Norwegian bird monitoring. The Swedish Bird Survey is supported by grants from the Swedish Environmental Protection Agency, with additional financial and logistic support from the Regional County Boards (Länsstyrelsen). The censuses were carried out within the framework of the Linnaeus-project Centre for Animal Movement Research (CAnMove) and the strategic 
research environment Biodiversity and Ecosystem Services in a Changing Climate (BECC). MS was supported by a grant from FORMAS (226-2013-1204). The Ministry of Environment financially supports Finnish bird monitoring. This particular study was carried out within the framework of the 2017-2018 Belmont Forum and BiodivERsA joint call for research proposals, under the BiodivScen ERANet COFUND program, with support from the Academy of Finland (AKA), the Swedish Research Council (Formas), the National Research Council of Norway (RCN) and the U.S. National Science Foundation (NSF).

\section{REFERENCES}

Ahti, T., L. Hämet-Ahti \& J. Jalas. 1968. Vegetation zones and their sections in northwestern Europe. Annales Botanici Fennici 5: 169-211.

Amano, T., T. Székely, B. Sandel, S. Nagy, T. Mundkur, T. Langendoen, D. Blanco, C.U. Soykan \& W.J. Sutherland. 2018. Successful conservation of global waterbird populations depends on effective governance. Nature 553: 199-202.

Bart, J., S. Brown, B. Harrington \& R.I.G. Morrison. 2007. Survey trends of North American shorebirds: population declines or shifting distributions? Journal of Avian Biology 38: 73-82.

BirdLife International. 2015. European Red List of Birds. Office for Official Publications of the European Communities, Luxembourg.

Boogart, P., M. van der Loo \& J. Pannekoek. 2018. R Package rtrim. Accessed at: https://cran.r-project.org/web/ packages $/$ rtrim/rtrim.pdf

Boström, U. \& S.G. Nilsson. 1983. Latitudinal gradients and local variations in species richness and structure of bird communities on raised peat-bogs in Sweden. Ornis Scandinavica 14: 213-226.

Brommer, J.E., A. Lehikoinen \& J. Valkama. 2012. The breeding ranges of central European and northern boreal species move polewards. PLoS ONE 7: e43648.

Devictor V., R. Julliard, D. Couvet \& F. Jiguet. 2008. Birds are tracking climate warming, but not fast enough. Proceedings of the Royal Society B 275: 2743-2748.

EBCC/BirdLife/RSPB/CSO. 2019. Trends of common birds in Europe, 2017 update. Accessed 19 May 2019 at: http:// ebcc.birdlife.cz/trends-of-common-birds-in-europe-2017updatel

Franks, S E., J.W. Pearce-Higgins, S. Atkinson, J.R. Bell, M.S. Botham, T.M. Brereton, R. Harrington \& D.I. Leech. 2018. The sensitivity of breeding songbirds to changes in seasonal timing is linked to population change but cannot be directly attributed to the effects of trophic asynchrony on productivity. Global Change Biology 24: 957-971.

Fransson, T., H. Österblom \& S. Hall-Karlsson. 2008. Swedish bird ringing atlas, vol. 2. Naturhistoriska Riksmuseet, Stockholm, Sweden.

Fraixedas, S., A. Lindén, K. Meller, Å. Lindström, $O$. Keišs, J.A. Kålås, M. Husby, A. Leivits, M. Leivits \& A. Lehikoinen. 2017. Substantial decline of Northern European peatland bird populations: consequences of drainage.
Biological Conservation 214: 223-232.

Gregory, R.D., A. Van Strien, P. Vorisek, A.W.G. Meyling, D.G. Noble, R.P. Foppen \& D.W. Gibbons. 2005. Developing indicators for European birds. Philosophical Transactions of the Royal Society B 360: 269-288.

Gregory, R.D., P. Voří̌šek, A. Van Strien, A.W. Gmelig Meyling, F. Jiguet, L. Fornasari, J. Reif, P. Chylarecki \& I.J. Burfield. 2007. Population trends of widespread woodland birds in Europe. Ibis 149(Suppl. 2): 78-97.

Gunnarsson, T.G. \& G. Tómasson. 2011. Flexibility in spring arrival of migratory birds at northern latitudes under rapid temperature changes. Bird Study 58:1-12.

Heggøy, O. 2018. Hvor hekker Tjelden i Norge? Vår fuglefauna 41: 178-187. [In Norwegian]

Huntley, B., R.E. Green, Y.C. Collingham \& S.G. Willis. 2007. A climatic atlas of European breeding birds. Lynx Edicions, Barcelona, Spain.

International Panel on Climate Change (IPCC). 2014. Climate Change 2014: Synthesis Report. Contribution of Working Groups I, II and III to the Fifth Assessment Report of the Intergovernmental Panel on Climate Change (CoreWritingTeam, R.K. Pachauri \& L.A. Meyer, Eds.). IPCC, Geneva, Switzerland.

Järvinen, O. \& R.A. Väisänen. 1978. Ecological zoogeography of North European waders, or why do so many waders breed in the north? Oikos 30: 495-507.

Jiguet, F., R.D. Gregory, V. Devictor, R.E. Green, P. Vorisek, A. van Strien \& D. Couvet. 2010. Population trends of European common birds are predicted by characteristics of their climatic niche. Global Change Biology 16: 497-505.

Johansen, H. 1958. Revision und Entstehung der arktischen Vogelfauna II. Acta Arctica 9: 1-131. [In German]

Kålås, J.A. \& M. Husby. 2002. Terrestrisk naturovervåking. Ekstensiv overvåking av terrestre fugl $i$ Norge. NINA Oppdragsmelding 740, Trondheim, Norway. [In Norwegian with English abstract]

Koskimies, P. \& R.A. Väisänen. 1991. Monitoring Bird Populations. Zoological Museum, Finnish Museum of Natural History, Helsinki, Finland.

Kouki, J. 1999. Latitudinal gradients in species richness in northern areas: some exceptional patterns. Ecological Bulletins 47: 30-37.

Laaksonen, T.K. \& A. Lehikoinen. 2013. Population trends in boreal birds: continuing declines in long-distance migrants, agricultural and northern species. Biological Conservation 168: 99-107.

Lappo, E.G., P.S. Tomkovich \& E.E. Syroechkovskiy. 2012. Atlas of breeding waders in the Russian Arctic. Institute of Geology, Russian Academy of Sciences, Moscow, Russia. [In Russian with English summaries]

Lehikoinen, A. 2013. Climate change, phenology and species detectability in a monitoring scheme. Population Ecology 55: 315-323.

Lehikoinen, A., M. Green, M. Husby, J.A. Kålås \& Å. Lindström. 2014. Common montane birds are declining in northern Europe. Journal of Avian Biology 45: 3-14.

Lindström, Å. \& J. Agrell. 1999. Global change and possible effects on the migration and reproduction of arcticbreeding waders. Ecological Bulletins 47: 145-159. 
Lindström, Å., M. Green, G. Paulson, H.G. Smith \& V. Devictor. 2013. Rapid changes in bird community composition at multiple spatial scales in response to recent climate change. Ecography 36: 313-322.

Lindström, Å., M. Green, M. Husby, J.A. Kålås \& A. Lehikoinen. 2015. Large-scale monitoring of waders on their boreal and arctic breeding grounds in northern Europe. Ardea 103: 3-15.

Meltofte, H. \& P. Clausen. 2016. Trends in staging waders on the Tipperne Reserve, western Denmark, 1929-2014 with a critical review of trends in flyway populations. Dansk Ornitologisk Forenings Tidsskrift 110: 1-72.

Møller, A.P., D. Rubolini \& E. Lehikoinen. 2008. Populations of migratory bird species that did not show a phenological response to climate change are declining. Proceedings of the National Academy of Sciences 105: 16195-16200.

Ottosson, U., R. Ottvall, J. Elmberg, M. Green, R. Gustafsson, F. Haas, N. Holmqvist, Å. Lindström, L. Nilsson, M. Svensson, S. Svensson \& M. Tjernberg. 2012. The birds in Sweden - numbers and occurrence. SOF, Halmstad, Sweden. [In Swedish with English summary]

Pakanen, V.-M. \& O. Thorup. 2016. Apparent adult survival of the critically endangered Baltic Dunlin Calidris alpina schinzii during a period of strong population decline. Bird Study 63: 293-302.

Pannekoek, J. \& A. van Strien. 2004. TRIM 3 Manual (TRends \& Indices for Monitoring data). Statistics Netherlands, Amsterdam, Netherlands. Accessed at: https://www.ebcc.info/art-13/

Pasek, J., A. Tahk, G. Culter \& M. Schwemmle. 2018. Weights: Weighting and Weighted Statistics. R package version 1.0. Accessed at: https://CRAN.R-project.org/package=weights

R Core Team. 2019. R: A language and environment for statistical computing, version 3.4.1. R Foundation for Statistical Computing, Vienna, Austria. Accessed at: http://www.Rproject.org/

Rakhimberdiev, E., S. Duijns, J. Karagicheva, C.J. Camphuysen, V.R.S. Castricum, A. Dekinga, R. Dekker, A. Gavrilov, J. ten Horn, J. Jukema, A. Saveliev, M. Soloviev, T.L. Tibbitts, J.A. van Gils \& T. Piersma. 2018. Fuelling conditions at staging sites can mitigate Arctic warming effects in a migratory bird. Nature Communications 9: 4263.

Ram, D., N.E.I. Nyholm, D. Arlt \& Å. Lindström. 2019. Small changes in timing of breeding among subarctic passerines over 32 years. Ibis 161: 730-743.

Rehfisch, M.M. \& H.Q.P. Crick. 2003. Predicting the impact of climatic change on Arctic-breeding waders. Wader Study Group Bulletin 100: 86-95.

Sanderson, F.J., P.F. Donald, D.J. Pain, I.J. Burfield \& F.P.J. van Bommel. 2006. Long-term population declines in Afro-Palearctic migrant birds. Biological Conservation 131: 93-105.

Simmons, R.E., H. Kolberg, R. Braby \& B. Erni. 2015. Declines in migrant shorebird populations from a winterquarter perspective. Conservation Biology 29: 877-887.

Soldaat, L.L., J. Pannekoek, R.J.T. Verweij, C.A.M. van Turnhout \& A.J. van Strien. 2017. A Monte Carlo method to account for sampling error in multi-species indicators. Ecological Indicators 81: 340-347.
Studds, C.E., B.E. Kendall, N.J. Murray, H.B. Wilson, D.I. Rogers, R.S. Clemens, K. Gosbell, C.J. Hassell, R. Jessop, D.S. Melville, D.A. Milton, C.DT. Minton, H.P. Possingham, A.C. Riegen, P. Straw, E.J. Woehler \& R.A. Fuller. 2017. Rapid population decline in migratory shorebirds relying on Yellow Sea tidal mudflats as stopover sites. Nature Communication 8: 14985.

Tayleur, C., V. Devictor, P. Gauzere, N. Jonzén, H.G. Smith \& Å. Lindström. 2016. Regional variation in climate change winners and losers highlights the rapid loss of cold-dwelling species. Diversity \& Distributions 22: 468-480.

Tøttrup, A.P., R.H.G. Klaassen, M.W. Kristensen, R. Strandberg, Y. Vardanis, Å Lindström, C. Rahbek, T. Alerstam \& K. Thorup. 2012. Drought in Africa caused delayed arrival of European songbirds. Science 338: 1307.

Väisänen, R.A. 2006. Monitoring population changes of 86 land bird species breeding in Finland in 1983-2005. Linnut-vuosikirja 2005: 83-98. [In Finnish with English summary]

Valkama, J, V. Vepsäläinen \& A. Lehikoinen. 2011. The Third Finnish Breeding Bird Atlas. Finnish Museum of Natural History and Ministry of Environment. Accessed at: http://atlas3.lintuatlas.fi/english ISBN 978-952-10-7145-4

van Bemmelen, R.S.A., J. Hungar, I. Tulp \& R.H.G. Klaassen. 2016. First geolocator tracks of Swedish red-necked phalaropes reveal the Scandinavia-Arabian Sea connection. Journal of Avian Biology 47: 295-303.

van Gils, J.A., S. Lisovski, T. Lok, W. Meissner, A. Ozarowska, J. de Fouw, E. Rakhimberdiev, M.Y. Soloviev, T. Piersma \& M. Klaassen. 2016. Body shrinkage due to Arctic warming reduces red knot fitness in tropical wintering range. Science 352: 819-821.

van Roomen M., S. Nagy, G. Citegetse \& H. Schekkerman (Eds.). 2018 East Atlantic Flyway Assessment 2017: the status of coastal waterbird populations and their sites. Wadden Sea Flyway Initiative p/a CWSS, Wilhelmshaven, Germany, Wetlands International, Wageningen, The Netherlands, BirdLife International, Cambridge, UK.

Waldenström, J. \& Å. Lindström. 2001. Migration and morphometrics of the Broad-billed Sandpiper Limicola falcinellus at Ottenby, southern Sweden, 1950-2000. Ornis Fennica 78: 184-192.

Wetlands International. 2012. Waterbird Population Estimates, Fifth Edition. Summary Report. Wetlands International, Wageningen, The Netherlands.

Wetlands International. 2017. Flyway trend analyses based on data from the African-Eurasian Waterbird Census from the period of 1967-2015. Wetlands International, Wageningen, The Netherlands. Accessed at: http://iwc.wetlands. org/static/files/0-IWC-trend-analysis-report-2017-final.pdf

Wetlands International. 2019. Waterbird Population Estimates. Accessed 19 May 2019 at: wpe.wetlands.org

Ydenberg, R.C., R.W. Butler, D.B. Lank, B.D. Smith \& J. Ireland. 2004. Western sandpipers have altered migration tactics as peregrine falcon populations have recovered. Proceedings of the Royal Sociey B 271: 1263-1269.

Zwarts, L., R.G. Biljsma, J. van der Kamp \& E. Wymenga. 2009. Living on the edge: Wetlands and birds in the changing Sahel. KNNV Publishing, Zeist, The Netherlands. 


\begin{tabular}{|c|c|c|c|c|c|c|c|c|c|c|c|c|c|c|c|c|c|c|c|c|c|c|c|}
\hline$\stackrel{\tilde{s}}{=}$ & $\begin{array}{l}\stackrel{9}{9} \\
\frac{1}{2}\end{array}$ & $=$ & 商 & $\sigma$ & - & $\stackrel{\hat{I}}{=}$ & 壳 & $\stackrel{ \pm}{ \pm}$ & in & $\stackrel{\widetilde{m}}{\tilde{m}}$ & $\stackrel{\circ}{\circ}$ & $\bar{\lambda}$ & $\hat{g}$ & 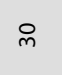 & \pm & $\stackrel{a}{a}$ & $\stackrel{\circ}{\circ}$ & 0 & $\sim$ & $m$ & $\approx$ & $a$ & $\sigma$ \\
\hline 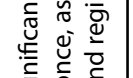 & $\frac{\xi}{\underline{\underline{z}}}$ & 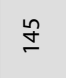 & $\begin{array}{l}\infty \\
\substack{\infty \\
m \\
m}\end{array}$ & g & $\therefore$ & $\stackrel{\underset{\sim}{\sim}}{\sim}$ & 总 & $\stackrel{\sigma}{m}$ & గิ & $\frac{n}{\sigma}$ & $\stackrel{\widetilde{I}}{\underset{I}{ }}$ & 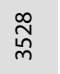 & 丞 & 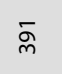 & $\stackrel{\infty}{\stackrel{\infty}{-1}}$ & $\stackrel{\text { I }}{\mathrm{N}}$ & $\stackrel{\infty}{\stackrel{\infty}{2}}$ & - & $\approx$ & $\stackrel{\infty}{m}$ & $\stackrel{\Phi}{\sim}$ & $\stackrel{̊}{\simeq}$ & in \\
\hline 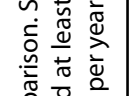 & 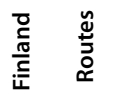 & 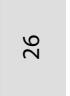 & $\stackrel{\bar{\infty}}{\stackrel{\Phi}{0}}$ & $\bar{\sim}$ & 0 & $E$ & 呼 & 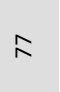 & $\stackrel{\tilde{n}}{\tilde{n}}$ & ల్ల & $\stackrel{\infty}{\stackrel{\infty}{\longleftarrow}}$ & 导 & నี & 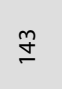 & m & $\Omega$ & $\frac{6}{m}$ & - & $a$ & in & $\stackrel{\infty}{q}$ & $\tilde{m}$ & \pm \\
\hline $\begin{array}{l}0 \\
0 \\
0\end{array}$ & in & & 娄 & & & $\tilde{z}$ & $*$ & $\tilde{z}$ & $\tilde{z}$ & * & $*$ & * & $\tilde{z}$ & $\tilde{z}$ & & $\tilde{z}$ & $\tilde{z}$ & & & & $*$ & & \\
\hline 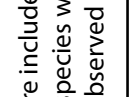 & 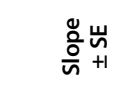 & & $\begin{array}{l}+1 \\
\text { ồ } \\
\text { ầं } \\
\text { o. }\end{array}$ & & & $\begin{array}{l}+1 \\
\text { on } \\
0 \\
0\end{array}$ & 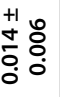 & $\begin{array}{l}+1 \\
+1 \\
0 \\
0 \\
0 \\
0 \\
0\end{array}$ & 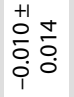 & 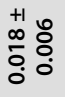 & $\begin{array}{l}+1 \\
0 \\
0\end{array}$ & 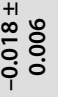 & 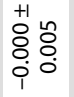 & - & & 每 & 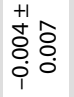 & & & & 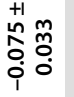 & & \\
\hline$\frac{u}{\tilde{u}}$ & $\begin{array}{l}\text { O) } \\
\text { In }\end{array}$ & $\sigma$ & 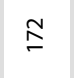 & ก & $\stackrel{\sim}{\sim}$ & శ్ర & ळे & $\sigma$ & $\stackrel{n}{m}$ & $\bar{m}$ & $\stackrel{\infty}{\infty}$ & $\underset{\sim}{\bar{I}}$ & ڤ્રે & $\bar{m}$ & 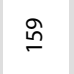 & $\stackrel{ \pm}{\sim}$ & $\overline{\bar{m}}$ & $=$ & $\stackrel{n}{\sim}$ & $\mathcal{F}$ & in & $\stackrel{\infty}{-}$ & $\stackrel{\sim}{\sim}$ \\
\hline 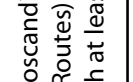 & $\frac{E}{\underline{\underline{z}}}$ & i̊ & $\stackrel{\substack{N \\
\sim}}{\sim}$ & ț & $\frac{\sigma}{m}$ & $\begin{array}{l}0 \\
\stackrel{0}{0} \\
\infty\end{array}$ & $\begin{array}{c}\infty \\
\substack{\infty \\
\infty \\
m}\end{array}$ & $\tilde{\text { ก }}$ & 孚 & 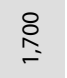 & $\underset{\substack{\tilde{y} \\
\sim}}{N}$ & $\underset{m}{\stackrel{N}{m}}$ & 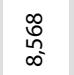 & 怘 & $\underset{\substack{\text { i } \\
\text { N }}}{ }$ & $\frac{t}{m}$ & 察 & $\underset{\Xi}{\ddagger}$ & à & 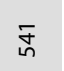 & $\hat{6}$ & $\stackrel{\widetilde{N}}{\sim}$ & $\underset{ల}{ \pm}$ \\
\hline 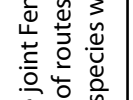 & 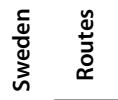 & $=$ & $\hat{\infty}$ & $\mathcal{F}$ & $\stackrel{\infty}{m}$ & $\stackrel{8}{\circ}$ & $\stackrel{\stackrel{\sim}{\gamma}}{\gamma}$ & $\tilde{\sim}$ & ণ্ & $\stackrel{\infty}{\simeq}$ & 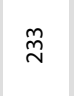 & $\stackrel{P}{m}$ & $\stackrel{\triangleright}{m}$ & $\underset{\sim}{\mathbb{D}}$ & $\stackrel{m}{\underline{m}}$ & $\stackrel{\circ}{2}$ & 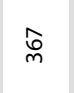 & 0 & $\tilde{m}$ & ని & $\stackrel{\sim}{\sim}$ & in & $m$ \\
\hline$\underline{\xi} \xi \underline{\xi}$ & in & & 粶 & $\tilde{z}$ & $\tilde{z}$ & $*$ & $\tilde{z}$ & & $\tilde{z}$ & * & $\tilde{z}$ & $\tilde{z}$ & * & $\tilde{z}$ & * & $\tilde{z}$ & $\tilde{z}$ & & $\tilde{z}$ & $*$ & & $\tilde{z}$ & $\tilde{z}$ \\
\hline 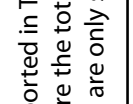 & 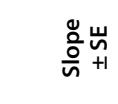 & & 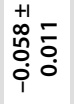 & 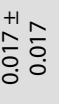 & 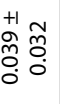 & $\begin{array}{l}+1 \\
\text { H. } \\
\vdots \\
\vdots \\
0\end{array}$ & 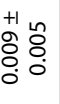 & & 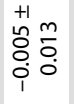 & 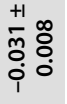 & 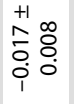 & 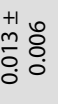 & $\begin{array}{l}+1 \\
\sum_{0}^{+1} \\
0 \\
0\end{array}$ & 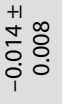 & 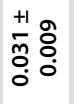 & 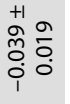 & $\begin{array}{l}+1 \\
0 \\
0 \\
0 \\
0\end{array}$ & & 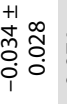 & 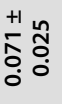 & & n & 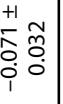 \\
\hline క్ & $\begin{array}{l}\frac{9}{\pi} \\
\frac{\pi}{2}\end{array}$ & $\bar{\sigma}$ & $\bar{N}$ & $\stackrel{\infty}{\sim}$ & $\stackrel{i}{ }$ & 广్ & $\stackrel{\infty}{\circ}$ & $\sim$ & $\stackrel{i}{i}$ & f & $\stackrel{0}{g}$ & $\stackrel{m}{m}$ & $\infty$ & $\stackrel{\circ}{\circ}$ & g & $\sim$ & $\stackrel{n}{\circ}$ & $\sigma$ & $\nabla$ & $\stackrel{\text { m }}{ }$ & 0 & $a$ & $\infty$ \\
\hline 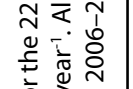 & $\frac{\xi}{\bar{n}}$ & হ̄ & $\stackrel{\sim}{~}$ & ర్లి & $\stackrel{\widetilde{N}}{\sim}$ & $\underset{\substack{\infty \\
\infty \\
\infty}}{ }$ & $\frac{\infty}{\sim}$ & $\stackrel{\circ}{\circ}$ & 总 & $\bar{\jmath}$ & @̊ & $\underset{\Im}{\infty}$ & $\underset{\Xi}{\cong}$ & $\underset{\substack{m \\
-}}{ }$ & 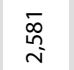 & $\approx$ & 䍐 & in & f & 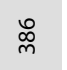 & $\sim$ & $\stackrel{\cong}{\simeq}$ & $\stackrel{\widetilde{\Omega}}{\circ}$ \\
\hline 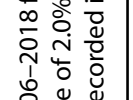 & 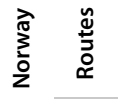 & 8 & $\mathcal{F}$ & 6 & in & $\stackrel{\infty}{\sim}$ & $\hat{\tilde{N}}$ & $=$ & શิ & ธి & 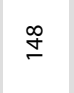 & $\bar{\sigma}$ & $\overline{\underline{m}}$ & $\widehat{\tilde{N}}$ & 离 & $\infty$ & $\stackrel{ก}{\check{2}}$ & i & $\stackrel{\sim}{\circ}$ & \& & - & $\stackrel{\sim}{\sim}$ & $\hat{\sim}$ \\
\hline$\frac{\breve{d}}{0}$ & 유 & $\tilde{z}$ & 粶 & $\tilde{z}$ & $\tilde{z}$ & $*$ & $*$ & & $\Sigma$ & $\tilde{z}$ & * & $\tilde{z}$ & $\tilde{z}$ & $\tilde{z}$ & $\tilde{z}$ & & $\Sigma$ & & & $\tilde{z}$ & & & \\
\hline 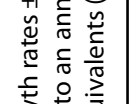 & 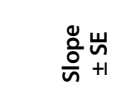 & 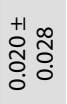 & 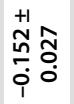 & 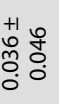 & 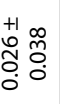 & 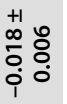 & 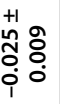 & & 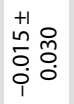 & 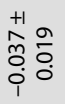 & 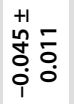 & 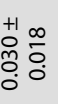 & 낭 & 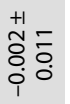 & 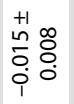 & & 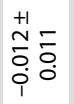 & & & 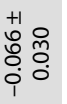 & & & \\
\hline 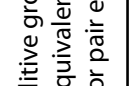 & $\begin{array}{l}\stackrel{0}{2} \\
\frac{\pi}{2}\end{array}$ & 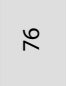 & gे & $\infty$ & \& & $\underset{J}{\stackrel{m}{J}}$ & $\bar{N}$ & $\stackrel{m}{m}$ & $\stackrel{\circ}{\circ}$ & ī & q & $\stackrel{\vartheta}{n}$ & I্] & : & $\underset{m}{\stackrel{N}{m}}$ & \& & in & $\stackrel{\sim}{\sim}$ & $\stackrel{\sim}{\text { i }}$ & $\stackrel{ \pm}{\wedge}$ & $\grave{\lambda}$ & $\stackrel{\circ}{m}$ & $\hat{m}$ \\
\hline 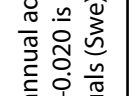 & $\frac{\xi}{\underline{\underline{z}}}$ & ล̃ & 离 & $\stackrel{\infty}{\stackrel{\infty}{\infty}}$ & 吕 & 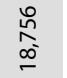 & $\underset{\substack{n \\
n \\
\sigma}}{n}$ & ஓ్ & 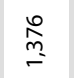 & స్ & $\begin{array}{l}\hat{n} \\
\hat{n} \\
\hat{n}^{2}\end{array}$ & $\stackrel{\infty}{\stackrel{\infty}{n}}$ & $\frac{\bar{n}}{\sigma}$ & 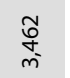 & 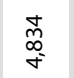 & î & $\begin{array}{l}\text { 吕 } \\
\stackrel{2}{N}\end{array}$ & $\bar{i}$ & 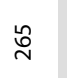 & ळ̊ & $\stackrel{\mathscr{N}}{n}$ & $\tilde{F}$ & $\stackrel{\sim}{\sim}$ \\
\hline$\underset{\pi}{0}$ & 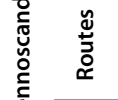 & $\stackrel{m}{\circ}$ & $\stackrel{\circ}{m}$ & 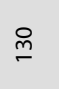 & nn & : & $\stackrel{\infty}{\stackrel{\infty}{=}}$ & $\Xi$ & 吕 & in & :̊̊ి & \&̊ & ○े & 总 & $\stackrel{6}{7}$ & $\stackrel{0}{6}$ & 岕 & $\bar{\lambda}$ & $\overline{6}$ & $\Omega$ & $\approx$ & $\stackrel{\circ}{\circ}$ & $\stackrel{N}{N}$ \\
\hline 5 & in & * & $\tilde{z}$ & $\tilde{z}$ & $\tilde{z}$ & $\tilde{z}$ & $\tilde{z}$ & $\check{z}$ & $\tilde{z}$ & $\tilde{z}$ & * & $\tilde{z}$ & * & $\tilde{z}$ & $\Sigma$ & $\tilde{z}$ & $\tilde{z}$ & $\tilde{z}$ & $\tilde{z}$ & $*$ & $*$ & $\tilde{z}$ & ** \\
\hline ญ & 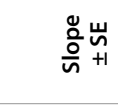 & 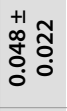 & 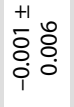 & 茾 & $\approx$ & $\begin{array}{l}+1 \\
\text { on } \\
0\end{array}$ & 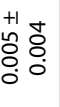 & 童 & $\begin{array}{l}\text { ol } \\
\text { ò } \\
0 \\
i\end{array}$ & - & $\begin{array}{l}\text { mo } \\
\text { co } \\
i \\
i\end{array}$ & 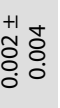 & 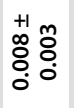 & 送 & 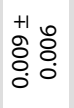 & 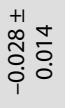 & 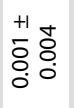 & $\begin{array}{l}0 \\
0\end{array}$ & 势 & 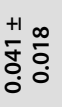 & 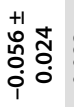 & مै & |ct \\
\hline 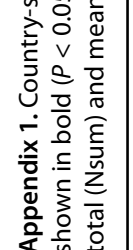 & $\begin{array}{l}\frac{\ddot{u}}{\overleftarrow{u}} \\
\dot{n}\end{array}$ & 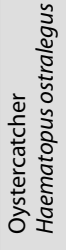 & 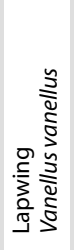 & 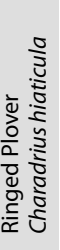 & 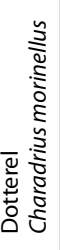 & 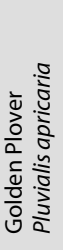 & 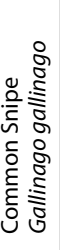 & 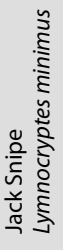 & 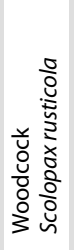 & 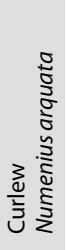 & 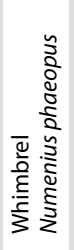 & 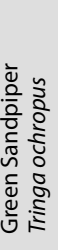 & 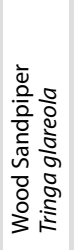 & 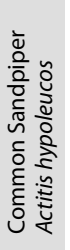 & 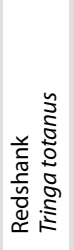 & 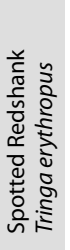 & 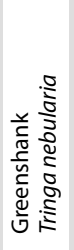 & 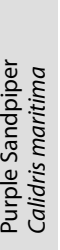 & 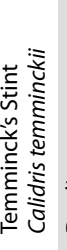 & 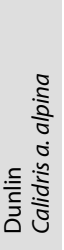 & 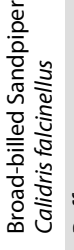 & 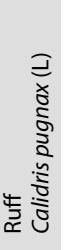 & 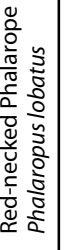 \\
\hline
\end{tabular}

